\title{
Innovation for and from emerging countries: a closer look at the antecedents of trickle-down and reverse innovation
}

\author{
Verdiana Giannetti ${ }^{1}$ (D) $\cdot$ Gaia Rubera ${ }^{2}$
}

Received: 29 August 2018 / Revised: 26 May 2019 / Accepted: 29 May 2019 / Published online: 24 June 2019

(C) The Author(s) 2019

\begin{abstract}
International new product launch speed is a crucial goal for firms, as it has major implications for their performance. The authors examine whether and how (1) the price and number of attributes of a new product, (2) the number of developed (emerging) countries in which it has been launched, and (3) the nature of the firm that originally launched it (i.e., multinational versus not) affect the new product's speed of launch from developed countries to emerging ones (i.e., trickle-down) or vice versa (i.e., reverse innovation). In order to test the hypotheses, the authors use data on new product launches in the global packaged food industry in 2001-2014. The results indicate that a lower price accelerates trickle-down, while a higher price and more attributes accelerate reverse innovation. Further, having been launched in more countries and having been launched by a multinational firm both accelerate trickle-down and reverse innovation.
\end{abstract}

Keywords Emerging countries $\cdot$ Trickle-down $\cdot$ Reverse innovation $\cdot$ Marketing mix $\cdot$ International new product launches

\section{Introduction}

International new product launch speed is a crucial goal for firms as it has major implications for their cash flows and profits (Hultink et al. 1998; Verniers et al. 2011; Yeniyurt et al. 2007). Faster new product launches allow firms to enter the market before competitors, gaining a pioneer advantage (Kessler and Chakrabarti 1999) and extending the product's sales life (Karagozoglu and Brown 1993).

Rajendra Srivastava and V. Kumar served as Special Issue Guest Editors for this article.

Electronic supplementary material The online version of this article (https://doi.org/10.1007/s11747-019-00669-3) contains supplementary material, which is available to authorized users.

Verdiana Giannetti

v.giannetti@leeds.ac.uk

Gaia Rubera

gaia.rubera@unibocconi.it

1 Leeds University Business School, Marketing Division, University of Leeds, Maurice Keyworth Building, Leeds LS2 9JT, UK

2 Department of Marketing, BIDSA, Gucci Research Lab, Bocconi University, Via Roentgen 1, 20136 Milan, Italy
Understanding the drivers of international new product launch speed is hence critical in today's global marketplace, where multinational firms (MNCs, hereinafter) increasingly derive profits from the launch of new products in emerging countries (Bahadir et al. 2015; Ernst et al. 2015). However, difficulties in understanding emerging countries' consumers make this practice challenging for Western MNCs (Bahadir et al. 2015; Ernst et al. 2015; Sheth 2011). MNCs also face the risk of seeing local firms imitating in emerging countries products that MNCs originally launched in developed countries. Finally, MNCs are exposed to competition from emerging countries' firms in their own domestic markets, with emerging countries' firms rapidly launching in developed countries products that were originally launched in emerging countries (Ramamurti and Singh 2009; Sheth 2011). Thus, managers of MNCs have to tackle three relevant problems: (1) adapting their new products to accelerate their launch in emerging countries; (2) preempting imitation of their new products by local firms in emerging countries; (3) defending their established positions in developed countries from new product launches by emerging countries' firms. Theoretical and empirical issues have, so far, greatly limited our understanding of these problems.

From a theoretical perspective, while different streams of research have shed light on specific elements of the picture described above, the existing literature fails to offer a comprehensive framework that explains all the challenges that MNCs 
face in today's global marketplace. From an empirical perspective, existing studies have been limited to qualitative cases of Western MNCs like PepsiCo (Govindarajan and Trimble 2012) and, more rarely, MNCs from emerging countries like Tata (Govindarajan and Ramamurti 2011), in a limited set of emerging countries such as India or China. Thus, they have neglected local firms, which may represent serious competitors for Western MNCs, as well as some of the fastest-growing emerging countries, which may represent profitable markets where to launch their new products for Western MNCs.

Such theoretical and empirical limitations have led to a simplified picture of competitive dynamics in today's global marketplace. Hence, we develop a comprehensive theoretical framework and test it in an extensive dataset that includes both global MNCs and small local firms, operating in a large set of emerging and developed countries. We believe that such thorough theoretical and empirical efforts, by highlighting the specific role of emerging countries, as well as of emerging countries' firms, provide a more realistic picture of the complexities that characterize today's global marketplace.

In particular, we develop a theoretical framework that merges four streams of literature: (1) international new product launch speed (Verniers et al. 2011; Yeniyurt et al. 2007); (2) innovation for and from emerging countries (Prahalad 2004; Sheth 2011); (3) innovation diffusion and adoption in the global marketplace (Ganesh and Kumar 1996); and (4) imitation of new products (Giachetti and Lanzolla 2016). Our framework (1) studies, consistent with the literature on international new product launch speed, the antecedents of the speed of two types of international new product launch: trickle-down (i.e., the launch in emerging countries of new products initially launched in developed countries) and reverse innovation (i.e., the launch in developed countries of new products initially launched in emerging countries); (2) identifies in product price and number of attributes the two main antecedents of the speed of trickle-down (reverse innovation), consistent with the literature on innovation for and from emerging countries; (3) investigates the role of past launches in other countries in influencing the speed of trickle-down (reverse innovation), consistent with the literature on innovation diffusion and adoption in the global marketplace; (4) examines, consistent with the literature on imitation, the extent to which products originally launched by MNCs (versus not) experience a faster trickle-down (reverse innovation), either through launches by the same firm or by imitation.

We test our framework in the global packaged food industry. This context is appropriate given the pervasiveness of trickle-downs and reverse innovations (Govindarajan and Trimble 2012), as well as of cross-country imitation, due to low intellectual property rights (IP, hereinafter). We combine multiple data sources including the Mintel GNPD Database, the World Bank Database, and the CIA World Factbook. The data include 127,782 new product launches in 51 countries in the 2001-2014 period. Given the right-censored nature of data, and consistent with the literature on international new product launch speed (Danzon et al. 2005), we test the hypotheses with a proportional hazard model.

We contribute to the literature in several ways, theoretically and empirically. We advance a comprehensive theoretical framework to investigate the antecedents of new product launch speed across developed and emerging countries. Collectively, our findings may help managers (1) modify existing new products to enter foreign markets more quickly, (2) forecast which new products will enter domestic markets more quickly, (3) identify which of their new products are particularly susceptible to foreign imitation.

We also contribute to each stream of literature. First, we extend the literature on international new product launch speed by focusing on product-level marketing mix antecedents (i.e., price and number of attributes), while past studies focused on firm- and country-level ones. Since marketing mix elements are the levers available to managers to accelerate international new product launches, we provide them with actionable implications on how to modify the price and number of attributes of new products to successfully compete in today's global marketplace.

Second, we contribute to the literature on innovation for and from emerging countries, which has been largely anecdotal (Ernst et al. 2015). We provide the first large-scale assessment of how products move from developed countries to emerging ones and vice versa. We are the first to empirically examine the characteristics of products that accelerate trickle-down and reverse innovation. We thus add to the limited literature that addresses how differences between emerging and developed countries may influence the effects of marketing mix elements (Bahadir et al. 2015). Documenting how product characteristics affect the speed of trickle-down and reverse innovation has great value for scholars and managers operating in today's global marketplace, who, so far, have a limited understanding and scant guidance about how to compete in this new environment. By showing that the same marketing mix element may display opposing effects in emerging and developed countries, our findings point out to managers the necessity of tailoring marketing mix decisions to the specific nature of the country that they are targeting. Since our dataset includes many emerging and developed countries ( 24 and 27 , respectively), as well as both MNCs and local firms, our findings are generalizable to a variety of countries and types of firms.

Third, our results also add to the literature on innovation diffusion and adoption in the global marketplace by showing that cross-country learning effects not only influence the performance of new products in specific countries but also the speed at which new products are launched in different countries.

Finally, we investigate cross-country imitation in both developed and emerging countries. In doing so, our findings add to the literature on imitation, which has so far focused on imitation within specific countries, emerging countries in particular. 


\section{Theoretical background}

In this section, we review four theoretical streams of literature that are relevant to our understanding of how new products are launched in today's global marketplace. We start by reviewing the literature on international new product launch speed, which explicitly studies how fast new products are launched in different countries. We then bring forth the limitations of this literature in light of the characteristics of today's global marketplace. We hence turn to review three streams of literature (i.e., innovation for and from emerging countries, innovation diffusion and adoption in the global marketplace, and imitation of new products) whose theoretical insights enable us to overcome these limitations. Please see Table 1 for a synthesis of the above-mentioned streams of literature.

\section{International new product launch speed}

The extant literature on international new product launch speed mainly focuses on the antecedents of international new product launch speed, specifically, firm- and countrylevel antecedents. At the firm-level, noted antecedents include global and local experience (Danzon et al. 2005; Kyle 2007, 2006; Townsend et al. 2009; Yeniyurt et al. 2007), previous launches (Kyle 2007, 2006), and multinationality of the launching firm (Kyle 2006). At the country-level, they include market size (Danzon et al. 2005; Kyle 2007, 2006; Verniers et al. 2011; Yeniyurt et al. 2007), competition (Kyle 2007, 2006; Yeniyurt et al. 2007), and cultural distance (Kyle 2006; Townsend et al. 2009; Yeniyurt et al. 2007).

This literature presents four main gaps that limit our understanding of the antecedents of international new product launch speed in today's global marketplace. First, it neglects the differences between emerging and developed countries and how these differences may alter the effects of the abovementioned firm- and country-level antecedents. Second, it neglects the role of the product-level marketing mix antecedents of international new product launch speed. Third, it treats international new product launches in isolation, with no consideration for how the past history of launches of a new product in other countries may affect the speed of its subsequent launch in new countries. ${ }^{1}$ Finally, most research has been conducted in IP-intensive industries, i.e., pharmaceutical and automotive, not allowing for the examination of the potential role of competitors in selecting products originally launched by other firms for launch in new countries. Imitation, however, is prominent in emerging countries because of nationalism, which encourages local firms to imitate products launched by

\footnotetext{
1 The only exception is Kyle $(2007,2006)$ who, using data from the pharmaceutical industry, shows that products that are launched in more countries are subsequently launched faster in new countries due to economies of scale in global production.
}

foreign MNCs (Luo et al. 2011), government-enacted import substitution, and motivation to imitate to catch-up with developed countries MNCs (Child and Rodrigues 2005).

\section{Innovation for and from emerging countries}

The past decade has witnessed the flourishing of a fertile area of research specifically focused on innovation for and from emerging countries (Zeschky et al. 2014). This literature has identified four international new product launch patterns, classified along two dimensions: (1) the first country in which the product is launched, distinguishing between developed and emerging countries, and (2) the subsequent countries in which the product is launched, distinguishing between developed and emerging countries:

I. Developed-only: New products initially launched in a developed country that are not subsequently launched in emerging countries;

II. Emerging-only: New products initially launched in an emerging country that are not subsequently launched in developed countries;

III. Trickle-down: New products initially launched in a developed country and subsequently in at least one emerging country;

IV. Reverse innovation (or Trickle-up): New products initially launched in an emerging country and subsequently in at least one developed country.

This literature has also theoretically identified two marketing mix elements, i.e., price and number of attributes, as the main antecedents of how fast a new product is launched from developed countries to emerging ones and vice versa. The accepted assumption is that lower-priced products are launched faster from developed to emerging countries and vice versa (Govindarajan and Trimble 2012; Prahalad 2004). However, the evidence concerning price is still essentially anecdotal in nature. Similarly, this literature has repeatedly advanced, from a theoretical perspective, the importance of the number of product attributes in driving trickle-down and reverse innovation (Govindarajan and Ramamurti 2011; Winter and Govindarajan 2015) but has not empirically tested this contention.

Further, the literature on innovation for and from emerging countries is still largely anecdotal, with a primary focus on India and China (Ernst et al. 2015). Hence, it neglects some of the largest (e.g., Brazil and Russia) and fastest-growing (e.g., Vietnam and Philippines) emerging countries. Despite calls to conduct more research on emerging countries $(\mathrm{Gu}$ et al. 2008; Sheth 2011), there is a dearth of quantitative analyses based on a large sample of countries (Ernst et al. 2015).

Notwithstanding these limitations, the literature on innovation for and from emerging countries enables us to enrich our 
Table 1 Review of the literature

\begin{tabular}{|c|c|c|c|}
\hline $\begin{array}{l}\text { Literature } \\
\text { Stream }\end{array}$ & Key Theoretical Insights & Main Limitations & $\begin{array}{l}\text { Main Contributions to Our Theoretical } \\
\text { Framework }\end{array}$ \\
\hline $\begin{array}{l}\text { International } \\
\text { New } \\
\text { Product } \\
\text { Launch } \\
\text { Speed }\end{array}$ & $\begin{array}{l}\text { Two main sets of antecedents of international new } \\
\text { product launch speed: } \\
\text { - Firm-level antecedents: } \\
\text { o Global and local experience (Danzon et al. 2005; } \\
\text { Kyle 2007, 2006; Townsend et al. 2009; Yeniyurt } \\
\text { et al. 2007), } \\
\text { o Previous launches (Kyle 2007, 2006), } \\
\text { - Multinationality of the launching firm (Kyle 2006); } \\
\text { - Country-level antecedents: } \\
\text { - Market size (Danzon et al. 2005; Kyle 2007, 2006; } \\
\text { Verniers et al. 2011; Yeniyurt et al. 2007), } \\
\text { Competition (Kyle 2007, 2006; Yeniyurt et al. } \\
\text { 2007), } \\
\text { Cultural distance (Kyle 2006; Townsend et al. 2009; } \\
\text { Yeniyurt et al. 2007). }\end{array}$ & $\begin{array}{l}\text { - No attention devoted to product-level } \\
\text { marketing mix antecedents; } \\
\text { - No distinction between emerging and } \\
\text { developed countries; } \\
\text { - No attention to how the history of past } \\
\text { launches of a new product may affect its } \\
\text { speed of subsequent launch in new } \\
\text { countries; } \\
\text { - Assumption that it is the same firm to } \\
\text { launch a new product across different } \\
\text { countries; } \\
\text { - Empirical studies conducted in } \\
\text { IP-intensive industries. }\end{array}$ & $\begin{array}{l}\text { - Focus on the antecedents of international } \\
\text { new product launch speed; } \\
\text { - Choice of control variables. }\end{array}$ \\
\hline $\begin{array}{l}\text { Innovation For } \\
\text { and From } \\
\text { Emerging } \\
\text { Countries }\end{array}$ & $\begin{array}{l}\text { - Two distinct types of international new product } \\
\text { launch: trickle-down (i.e., a product initially } \\
\text { launched in a developed country is eventually } \\
\text { launched in an emerging country) and reverse } \\
\text { innovation (i.e., a product initially launched in an } \\
\text { emerging country is eventually launched in a } \\
\text { developed country) (Govindarajan and Trimble } \\
\text { 2012); } \\
\text { - Two marketing mix elements, i.e., price and number } \\
\text { of attributes, contribute to determining whether and } \\
\text { how fast a new product experiences trickle-down or } \\
\text { reverse innovation (Govindarajan and Trimble } \\
\text { 2012; Govindarajan and Ramamurti 2011; Prahalad } \\
\text { 2004; Winter and Govindarajan 2015). }\end{array}$ & $\begin{array}{l}\text { - Anecdotal evidence based on case } \\
\text { studies; } \\
\text { - Primary focus on India and China (Ernst } \\
\text { et al. 2015); } \\
\text { - No attention to some of the largest (e.g., } \\
\text { Brazil and Russia) and fastest-growing } \\
\text { (e.g., Vietnam and Philippines) } \\
\text { emerging countries. }\end{array}$ & $\begin{array}{l}\text { - Focus on two specific types of international } \\
\text { new product launch: } \\
\text { o trickle-down, } \\
\text { o reverse innovation; } \\
\text { - Focus on two product-level marketing mix } \\
\text { antecedents of international new product } \\
\text { launch speed: } \\
\text { o price, } \\
\text { number of attributes. }\end{array}$ \\
\hline $\begin{array}{l}\text { Innovation } \\
\text { Diffusion } \\
\text { and } \\
\text { Adoption }\end{array}$ & $\begin{array}{l}\text { - Learning effect: consumers in lag countries learn } \\
\text { about the product from the experience of consumers } \\
\text { in the lead country (Ganesh and Kumar 1996; } \\
\text { Kalish et al. 1995); } \\
\text { - This learning helps accelerate the "time to sales } \\
\text { peak" of a new product in lag countries (Ganesh } \\
\text { and Kumar 1996). }\end{array}$ & $\begin{array}{l}\text { - Focus on the new product performance in } \\
\text { the country of launch (this study, } \\
\text { conversely, focuses on the speed of } \\
\text { cross-country new product launch); } \\
\text { - No attention to the firm(s) that launches } \\
\text { the product across countries. }\end{array}$ & $\begin{array}{l}\text { - The number of previous developed } \\
\text { (emerging) countries in which the product } \\
\text { has been launched may influence its speed } \\
\text { of trickle-down (reverse innovation). }\end{array}$ \\
\hline Imitation & $\begin{array}{l}\text { - MNCs are a natural target of imitation (Giachetti and } \\
\text { Lanzolla 2016; Lieberman and Asaba 2006): } \\
\text { Imitating MNCs helps reduce uncertainty and } \\
\text { increase legitimacy (Ordanini et al. 2008), } \\
\text { Local firms are fast at imitating MNCs for purposes } \\
\text { of spatial preemption (Lieberman and Montgomery } \\
\text { 1988). }\end{array}$ & $\begin{array}{l}\text { - Focus on imitation within countries (Lee } \\
\text { and Tang 2018; Lee and Zhou 2012; } \\
\text { Luo et al. 2011); } \\
\text { - Focus on imitation in emerging countries } \\
\text { (Lee and Tang 2018; Lee and Zhou } \\
\text { 2012; Luo et al. 2011). }\end{array}$ & $\begin{array}{l}\text { - The nature of the firm that launches the } \\
\text { product (i.e., MNC versus not) may } \\
\text { influence its speed of trickle-down (reverse } \\
\text { innovation). }\end{array}$ \\
\hline
\end{tabular}

theoretical framework with two important insights: (1) the identification of two specific types of international new product launch, i.e., trickle-down and reverse innovation, which are both specifically related to emerging countries; (2) the key role of product price and number of attributes as antecedents of the speed of trickle-down and reverse innovation.

\section{Innovation diffusion and adoption in the global marketplace}

In today's global marketplace, the launch of a new product in a specific country may have an effect on its subsequent launch in another country, as consumers observe what happens outside of their country (Kalish et al. 1995). This issue, however, is overlooked in the extant literature on international new product launch speed. The literature on innovation diffusion and adoption in the global marketplace, conversely, shows that previous launches of a new product in other countries may influence its "time to sales peak" in the subsequent countries where the new product is launched. Consumers in countries where the new product is launched later (i.e., lag countries), in fact, often learn from the experience of consumers in the countries where the product was originally launched (i.e., lead countries) (Ganesh et al. 1997; Ganesh and Kumar 1996; Kumar 2014). Due to this "learning effect", the time to sales peak for the new product is shorter in lag countries (Ganesh and Kumar 1996), as consumers in the lag countries have the opportunity to observe the product in the lead countries and learn about it. This, in turn, reduces the perceived risk associated with the purchase of the product (Kalish et al. 1995). This stream of research seems to suggest that the history of past launches of a new product may influence the speed of its subsequent launch in new countries. Knowing that consumers are more ready to adopt new products previously launched in 
other countries, we could expect products that were launched in more developed (emerging) countries to experience a faster trickle-down (reverse innovation). Hence, we include this theoretical insight in our framework.

\section{Imitation of new products in the global marketplace}

The literature on international new product launch speed has always acted under the assumption that it is the same firm to launch a product across different countries. This assumption is no longer realistic in today's global marketplace, in which new products launched by a firm in a given country can be (and are) imitated by other firms in other countries. For instance, Western MNCs synthesize, and sell as FDA-approved drugs in the U.S., natural ingredients that have been used in India for many years (Von Zedtwitz et al. 2015). Crosscountry imitation is thus a relevant empirical phenomenon that is much neglected in the international new product launch speed literature. This type of imitation is particularly common in our empirical context, i.e., the packaged food industry, where IP are very difficult to obtain (USPTO 2013).

To fill this gap, we draw theoretical insights from the literature on imitation (Giachetti and Lanzolla 2016; Lieberman and Asaba 2006), which maintains that new products introduced by MNCs are imitated faster than new products introduced by local firms. However, while the mainstream literature on imitation has mainly focused on within-country imitation, we investigate cross-country imitation ${ }^{2}$ of new products.

\section{Hypotheses}

We combine the above-mentioned streams of literature to develop our comprehensive theoretical framework (Please see Fig. 1). Given our emphasis on emerging countries, we focus on two specific types of international new product launch, i.e., trickle-down and reverse innovation. In particular, we identify the following antecedents of the speed of trickle-down and reverse innovation: (1) product price and number of attributes (from the literature on innovation for and from emerging countries); (2) number of countries in which the product has been previously launched (from the literature on innovation diffusion and adoption in the global marketplace); (3) multinationality of the launching firm (from the literature on imitation).

\section{Price}

Trickle-down We argue that products with a lower price will experience a faster trickle-down for two main reasons. First,

\footnotetext{
${ }^{2}$ We refer to legal imitation, i.e., imitation that does not involve patent infringement.
}

the literature on innovation for emerging countries argues that, in pursuing trickle-down, firms should reduce the price of products (Govindarajan and Trimble 2012; Winter and Govindarajan 2015). Per capita income is, in fact, a critical discriminant between consumers in emerging and developed countries, with the former having a much smaller disposable income (Chandrasekaran et al. 2013; Ernst et al. 2015; Govindarajan and Ramamurti 2011). It is hence not surprising that the literature has identified price as the key force behind the adoption of innovations in emerging countries (Hart and Christensen 2002; Williamson 2010). Second, independently of their income, consumers from emerging countries are more price-conscious and price-sensitive than consumers from developed countries (Ackerman and Tellis 2001). Hence, we hypothesize a demand-pull mechanism (Von Hippel 1976) and argue that products with a lower price will be launched faster in emerging countries to meet the needs of financially constrained consumers. More formally, we propose the following:

H1a: Among new products initially launched in developed countries, those characterized by a lower price will experience a faster trickle-down.

Reverse innovation We argue that products with a higher price will experience a faster reverse innovation for the following reason. The past research has shown that consumers in developed countries use price to infer quality, as superior quality typically commands a higher price (Gerstner 1985; Tellis 1986). The price-signaling of quality is common for new products, whose quality level is still unclear. The problem of quality becomes particularly salient when consumers in developed countries have to buy products originally launched in emerging countries, as they may be suspicious about components and production standards (Haubl and Elrod 1999; Heslop and Papadopoulos 1993). Thus, a higher price associated with a product initially targeted at emerging countries can lead consumers in developed countries to be more confident about its quality. Hence, we hypothesize a demand-pull mechanism and argue that products with a higher price will be launched faster in developed countries. More formally, we propose the following:

H1b: Among new products initially launched in emerging countries, those characterized by a higher price will experience a faster reverse innovation.

\section{Number of attributes}

Trickle-down We argue that products with fewer attributes will experience a faster trickle-down for two main reasons. First, the literature on innovation for emerging countries emphasizes the need for new products launched in emerging countries to 


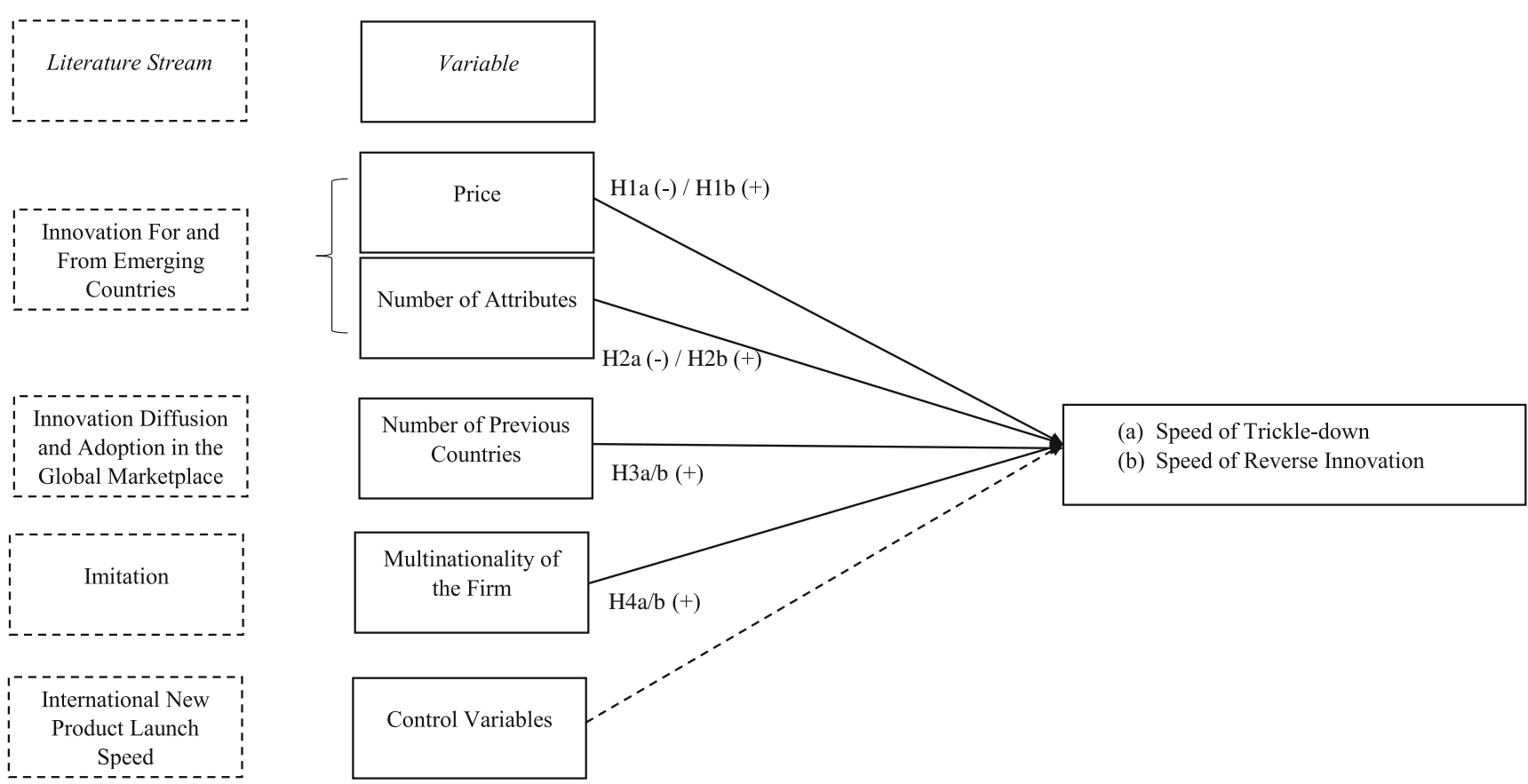

Fig. 1 Theoretical framework. Note: The dashed line refers to the effects that are not formally hypothesized in the interest of brevity

be defeatured. In fact, consumers in emerging countries are willing to accept a 50\% reduction in performance for a $75 \%$ price reduction (Govindarajan and Trimble 2012). Second, many attributes can limit consumers' ability to process information and increase confusion (Malhotra 1982). This problem is particularly salient when consumers have low functional literacy, where being functionally literate refers to having the language and numeracy competencies required to function adequately in day-to-day life (Kirsch and Guthrie 1977). According to the UNESCO Institute for Statistics (2008), today, the vast majority of the functionally illiterate population in the world is concentrated in emerging countries due to poverty and low educational levels. As a consequence, the complexity of new products must be limited as low-literate consumers may have difficulties in processing it. Hence, we hypothesize a demand-pull mechanism and argue that products with fewer attributes will be launched faster in emerging countries. More formally, we propose the following:

H2a: Among new products initially launched in developed countries, those characterized by fewer attributes will experience a faster trickle-down.

Reverse innovation We argue that products with more attributes will experience a faster reverse innovation for two main reasons. First, Govindarajan and Trimble (2012) and Govindarajan and Ramamurti (2011) argue that products originally intended for emerging countries are launched in developed countries through a process of progressive improvement. Second, like price, more attributes may act as signals of quality as consumers in developed countries may be particularly skeptical of quality when products come from emerging countries (Haubl and Elrod 1999; Heslop and Papadopoulos 1993). More attributes associated with a new product initially targeted at emerging countries can lead consumers in developed countries to be more confident about its quality. Hence, we hypothesize a demand-pull mechanism and argue that products with more attributes will be launched faster in developed countries. More formally, we propose the following:

H2b: Among new products initially launched in emerging countries, those characterized by more attributes will experience a faster reverse innovation.

\section{Number of previous countries}

We argue that new products that are launched in more developed (emerging) countries will experience a faster trickledown (reverse innovation) for the following reason.

According to the literature on innovation diffusion and adoption in the global marketplace (Ganesh et al. 1997; Ganesh and Kumar 1996; Kalish et al. 1995; Kumar and Krishnan 2002; Kumar et al. 1998), consumers in lag countries learn from the experience of consumers in lead countries. When a new product is launched in numerous developed (emerging) countries, consumers in emerging (developed) potential lag countries have numerous opportunities to observe the product and learn about it. This, in turn, reduces the perceived risk associated with the purchase of the product (Kalish et al. 1995). Further, when the new product is launched in numerous developed (emerging) countries, consumers in emerging (developed) potential lag countries have a higher 
probability of contacting a consumer in one of the lead countries. Such interaction can increase the demand for the product (Tellis et al. 2003). Hence, we hypothesize a demand-pull mechanism and argue that firms will perceive the launch of a new product in a new country safer when the product has already been launched in several countries. This perception will in turn make firms more willing to quickly launch in new countries a product that has already been launched in many countries. Thus, we expect products that were launched in more developed (emerging) countries to experience a faster trickle-down (reverse innovation). More formally, we propose the following:

H3a(b): Among new products initially launched in developed (emerging) countries, those launched in more developed (emerging) countries will experience a faster trickle-down (reverse innovation).

\section{Multinationality of the launching firm}

We argue that new products that are launched by MNCs will experience a faster trickle-down (reverse innovation) for two reasons.

First, according to the neo-institutional theory of imitation (see e.g., Baum et al. 2000; Giachetti and Lanzolla 2016; Lieberman and Asaba 2006), larger firms are a natural target of imitation because they are more visible. Further, competitors may believe that such firms became successful because of their superior knowledge and understanding of future market conditions and consumers' needs (Abrahamson 1996). Market leaders can in turn become "fashion leaders" (Bikhchandani et al. 1998). Hence, the imitation of MNCs may occur for purposes of risk minimization (Head et al. 2002) and industry legitimacy (Fligstein 1985; Haunschild and Miner 1997), i.e., the best way to reduce uncertainty and gain legitimacy is to imitate the decisions of key players in the industry (Ordanini et al. 2008).

Second, as MNCs are more likely to launch their products in new countries, competitors may be faster in imitating their products and launching them in local markets for purposes of spatial preemption (Lieberman and Montgomery 1988), i.e., to fill product differentiation niches before MNCs do. Hence, we propose the following:

H4a(b): Among new products initially launched in developed (emerging) countries, those introduced by MNCs will experience a faster trickle-down (reverse innovation).

\section{Method}

We now describe our empirical context and data collection approach.

\section{Empirical context}

We select the packaged food industry as the context of empirical investigation for three reasons. First, the packaged food industry is a U.S. $\$ 1.8$ trillion market that has grown at $4 \%$ between 2001 and 2011 (Howard et al. 2011), which indicates that it is an economically substantive context. Second, product innovation is endemic in this industry (Van Heerde et al. 2004) and several scholars have selected it as their setting in the study of innovation (Cillo et al. 2018; Sorescu and Spanjol 2008). Third, the growing relevance of emerging countries in the packaged food industry makes it an appropriate context for our study. Whereas in 2001, emerging countries were responsible for $20 \%$ of sales in this industry, in 2011, they represented $34 \%$ and are expected to contribute to $70 \%$ of growth in the upcoming years (Howard et al. 2011), presumably taking on a crucial innovative role. Further, anecdotal evidence suggests that this industry is appropriate for our study. For instance, Govindarajan and Trimble (2012) make the case of PepsiCo snack Kurkure as constituting an exemplary case of reverse innovation. On the other hand, after being initially launched in the U.S., Cheetos, another PepsiCo snack, are now distributed in China and India, thus constituting a clear example of trickle-down. Another example of reverse innovation in the packaged food industry is that of Parmalat, which, in the 1990s, developed a new type of packaging in the form of a milk pouch to meet the needs of financially constrained consumers in emerging countries. The same product was later launched in developed countries as an environmentally friendly solution (Von Zedtwitz et al. 2015). ${ }^{3}$ Finally, given the low-IP nature of the packaged food industry, cross-country imitation is particularly easy to implement in this context. In the packaged food industry, firms have almost no legal way to protect their new products. As a result, each firm, wherever in the world, can observe the launch of a new product by another firm and launch it somewhere else. This makes the packaged food industry a particularly appropriate context to investigate how new products move from developed countries to emerging ones, and vice versa, independently from the firms that actually launch them, the focus of our research.

\section{Data}

We collect data on new product launches in 51 countries from Mintel GNPD, ${ }^{4}$ a database that records launches in the

\footnotetext{
${ }_{3}^{3}$ Examples of trickle-down and reverse innovation abound across multiple industries including medical devices, electronics, and automotive. Smartphones, originally launched in developed countries and today extremely prominent in emerging countries, are an example of trickle-down. Portable ultrasound machines, initially launched in China, have now been successfully launched in developed countries, thus constituting an exemplary case of reverse innovation (Von Zedtwitz et al. 2015).

${ }^{4}$ For a thorough description of the database, please see Solis (2016).
} 
packaged food industry and provides a wide range of detailed information including price, packaging claims, and the date a new product is launched in a country. The prior studies using this database include Calantone et al. (2014), Cillo et al. (2018), and Rubera et al. (2016). Mintel GNPD categorizes launches in five categories: New Product, New Packaging, New Variety, New Formulation, and Re-launch. To capture launches that contain a sufficient degree of novelty in terms of the benefits offered to consumers (Chandy and Tellis 1998), we focus on launches that are alternatively classified as "New Product" or "New Packaging". 5

As our analyses rely on tracking global launch patterns using the different launches associated with a product, we exercise particular care in cleaning the data to ensure that the same product is correctly identified even though it is reported with different names across different launches. For instance, "donuts" are also identified in the original database as "doughnuts." We consider these alternative labels to refer to the same product. Similarly, "apple and carrot juice" is originally identified by other names such as "apple-carrot juice," and "apple $\&$ carrot juice". Because we conduct these checks manually, and because Mintel GNPD comprises more than one million new product launches in the period under study, to make our analysis feasible, we focus on three categories: bakery, baby food, and snacks.

We limit our analysis to the 2001-2014 period. This is because we only have data on launches from June 1996-on. Hence, it is possible that we could wrongly code a new product as being launched for the first time after June 1996, when instead it was launched before. As an example, in our database, potato chips appear for the first time in September 1996 in Belgium. However, it is very likely that the product "potato chips" was launched for the first time much before 1996 therefore not being new when it first appears in our database. To resolve this issue and ensure that all the launches in our database represent actually new products when they first appear, we remove all products that were launched at least once before the end of 2000. It is reasonable to assume that products that never appear in our database before January 2001 (i.e., in the 1996-2000 period) are new when they first appear. As an example, Bloody Mary potato chips appear for the first time in October 2002 and hence are retained in our sample. Our final dataset comprises 66,810 new products that generated 127,782 launches in 51 countries between 2001 and 2014. Of these, 35,662 are developed-only (53\%), 24,538 emerging-only (37\%), 3,714 trickle-downs (6\%), and 2,896 reverse innovations (4\%). An overview of the structure of our dataset, where launches are nested in new products, is presented in Table WA1 in Web Appendix A.

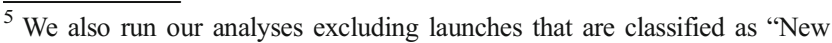
Packaging". The results do not change.
}

\section{Measures}

This section explains the measures in our study, which we report in Table 2.

Descriptive statistics and correlations are reported in Tables 6 and 7 in the Appendix. The variance inflation factors are all well below 10 (Hair et al. 2010).

Trickle-down We indicate trickle-down with a dummy variable that takes on a value of 1 if the new product is initially launched in a developed country and subsequently in at least one emerging country; 0 otherwise. We classify countries according to the World Economic Outlook, a report published twice a year by the International Monetary Fund. The WEO portrays the current condition of the world economy with projections for up to four years, including macroeconomic indicators such as GDP and fiscal balance. The only country undergoing a change in the classification in the period under study is the Czech Republic, which is classified as developed from 2009 on.

Reverse innovation We use a dummy variable that takes on a value of 1 if the new product is initially launched in an emerging country and subsequently in at least one developed country; 0 otherwise.

Time to trickle-down Time to trickle-down is the number of days between the first launch of the new product in a developed country and its first launch in an emerging country.

Time to reverse innovation Time to reverse innovation is the number of days between the first launch of the new product in an emerging country and its first launch in a developed country.

Price We measure a new product's price as the price in Euros of one unit of product.

Number of attributes This is a count variable that records the number of packaging claims associated with a given launch for a new product. Packaging claims are widely used to signal the attributes of products (Chandon 2013; Kozup et al. 2003). Examples of the packaging claims in our dataset are "glutenfree" or "sugar-free".

Number of previous countries This is a count variable that records the number of countries of the initial type (e.g., developed) in which the product has been launched before the current date.

Multinational We use a dummy variable that takes on a value of 1 if the firm that launches the product has launched products in more than 10 countries before the current date (Kyle 
Table 2 Variables, measures, and sources

\begin{tabular}{|c|c|c|c|}
\hline & Variable & Measure & Source \\
\hline \multirow{6}{*}{$\begin{array}{r}\text { Dependent } \\
\text { Variables } \\
\text { Independent } \\
\text { Variables }\end{array}$} & Trickle-down & 1 if the new product experiences trickle-down, 0 otherwise & \multirow{6}{*}{$\begin{array}{l}\text { Mintel GNPD, our } \\
\text { elaboration } \\
\text { Mintel GNPD, our } \\
\text { elaboration }\end{array}$} \\
\hline & Reverse Innovation & 1 if the new product experiences reverse innovation, 0 otherwise & \\
\hline & Price & Price in Euros of one unit of product & \\
\hline & Number of Attributes & Number of packaging claims associated with the product & \\
\hline & Previous Countries & $\begin{array}{l}\text { Number of countries of the initial type (e.g., developed) in which the product has been launched } \\
\text { before the current date }\end{array}$ & \\
\hline & Multinational & $\begin{array}{l}1 \text { if the launching firm has launched products in more than } 10 \text { countries before the current date, } \\
0 \text { otherwise }\end{array}$ & \\
\hline \multirow{9}{*}{$\begin{array}{l}\text { Control } \\
\text { Variables }\end{array}$} & Package Size & Product's weight in Grams & \multirow{2}{*}{$\begin{array}{l}\text { Mintel GNPD, our } \\
\text { elaboration }\end{array}$} \\
\hline & Previous Launches & $\begin{array}{l}\text { Product's number of launches in countries of the initial type (e.g., developed) before the current } \\
\text { date }\end{array}$ & \\
\hline & $\begin{array}{l}\text { Previous Countries } \\
\text { Sharing Borders }\end{array}$ & $\begin{array}{l}\text { Number of countries of the initial type (e.g., developed) in which the product has been launched } \\
\text { before the current date that share borders with at least one country with a different level of } \\
\text { development (i.e., emerging) }\end{array}$ & \multirow[t]{2}{*}{$\begin{array}{l}\text { Mintel GNPD and CIA } \\
\text { Intelligence Factbook, ou } \\
\text { elaboration }\end{array}$} \\
\hline & $\begin{array}{l}\text { Previous Countries } \\
\text { Sharing Language }\end{array}$ & $\begin{array}{l}\text { Number of countries of the initial type (e.g., developed) in which the product has been launched } \\
\text { before the current date that share a common official language with at least one country with a } \\
\text { different level of development (i.e., emerging) }\end{array}$ & \\
\hline & Category Experience & Launching firm's number of launches in the category of interest before the current date & \multirow{3}{*}{$\begin{array}{l}\text { Mintel GNPD, our } \\
\text { elaboration }\end{array}$} \\
\hline & $\begin{array}{l}\text { Experience in } \\
\text { Developed } \\
\text { Countries }\end{array}$ & Launching firm's number of launches in developed countries before the current date & \\
\hline & $\begin{array}{l}\text { Experience in } \\
\text { Emerging } \\
\text { Countries }\end{array}$ & Launching firm's number of launches in emerging countries before the current date & \\
\hline & Small Market & 1 if the focal country's population size is below the median in a given year & World Bank \\
\hline & Competition & $\begin{array}{l}\text { Number of new product launches in the focal subcategory in the focal country } \\
\text { before the current date }\end{array}$ & $\begin{array}{l}\text { Mintel GNPD, our } \\
\text { elaboration }\end{array}$ \\
\hline
\end{tabular}

2006) ${ }^{6} ; 0$ otherwise. Export diversity (i.e., the number of countries served by a firm) can in fact be used to measure the degree of internationalization (Dhanaraj and Beamish 2003; Sullivan 1994). We examine the MNCs in our dataset and find them to have high face validity. Examples of the MNCs in our dataset include General Mills, Mondelez, and PepsiCo. A percentage of $88 \%$ of the MNCs in our sample are based in developed countries. MNCs from emerging countries include Arcor (Argentina), Grupo Bimbo (Mexico), and Mayora Indah (Indonesia).

Control variables We include a number of control variables.

First, we control for package size, measured as the product's weight in grams, as the literature has evidenced its crucial role in innovating for emerging countries (see e.g., Prahalad 2004). We then control for previous launches by counting the number of times a given product has been launched in countries of the initial type (e.g., developed) before the current date (Kyle 2007; 2006), as we expect more successful products to be launched by more firms (see Tellis et al. 2003 for a similar logic). We derive these variables from Mintel GNPD. Further, in the case of trickle-down, we control for the cumulative number of developed countries in which the product has been launched before the current date that

\footnotetext{
${ }^{6}$ To compute this variable, we use data from the 1996-2014 period, while the analyses in the paper use data from the 2001-2014 period. This allows us to address the left-censoring of the variable. We proceed in an analogous way for the other left-censored control variables, i.e., firm experience and competition.
}

share (1) borders or a (2) common official language with at least one emerging country. We proceed similarly for reverse innovation. We derive these variables from Mintel GNPD and from the CIA Intelligence Factbook.

With respect to firm-level characteristics, consistent with the literature on international new product launch speed (Danzon et al. 2005; Kyle 2007, 2006; Townsend et al. 2009; Yeniyurt et al. 2007), we control for the launching firm experience in the category (e.g., snacks), which we measure as the number of launches a firm has undertaken in a category before the current date. Further, we measure firm experience in developed countries as the number of launches a firm has undertaken in developed countries before the current date. Similarly, we measure firm experience in emerging countries as the number of launches a firm has undertaken in emerging countries before the current date. We derive all these variables from Mintel GNPD.

With respect to country-level characteristics, we include market size using a small market dummy that takes on a value of 1 if the population size of the country is below the median in a given year; 0 otherwise (see Kyle 2007, 2006, Townsend et al. 2009, and Yeniyurt et al. 2007 for a similar logic). We derive this variable from the World Bank Database. We also include competition in the country, which we measure as the number of launches in the focal subcategory in the focal country before the current date (see Kyle 2007, 2006, Townsend et al. 2009, and Yeniyurt et al. 2007 for a similar logic). This variable is derived from Mintel GNPD. Finally, we include year and country fixed effects for the year and the country in 
which a product has been launched to control for possible unobserved heterogeneity across years and countries, respectively. We present detailed logic for the inclusion of the various control variables in Table WB1 in Web Appendix B.

\section{Results}

\section{Descriptives and model-free evidence}

Figure WC1 in Web Appendix C reports the distribution of trickle-downs (Figure WC1, Panel $a$ ) and reverse innovations (Figure WC1, Panel $b$ ) across emerging and developed countries, respectively. The country with the highest number of trickle-downs is Mexico (11\%), followed by China (10\%), and India (9\%). The country with the highest number of reverse innovations is the U.S. (15\%), followed by the U.K. (7\%), and Germany (7\%).

Figure 3 in the Appendix reports the 50 most common country sequences leading to trickle-down or reverse innovation. The red lines, connecting emerging countries (circles) to developed ones (squares), represent reverse innovations, while the blue lines, connecting developed countries to emerging ones, represent trickle-downs. The reported numbers indicate how many times the sequence occurs in the dataset. As the probability of incurring in identical sequences dramatically decreases when sequence length increases, they are all twocountries sequences. The most common trickle-down sequence is from the U.S. to Mexico (129), while the most common reverse innovation sequence is from Mexico to the U.S. (75). In the analyses, we control for whether the countries in which a product has been previously launched share borders with countries with a different level of development.

On average, it takes 1,332 days for a product to experience trickle-down and 1,177 days for a product to experience reverse innovation. The difference between the two time-lags, i.e., 155 days, is statistically significant $(\mathrm{t}=6.05, p<0.01)$, thus suggesting that, on average, reverse innovation takes less time than trickle-down to occur.

Trickle-down products have a higher price (2.64 versus $1.89, \mathrm{t}=22.41, p<0.01)$ and more attributes $(1.88$ versus $1.69, \mathrm{t}=7.10, p<0.01)$ when sold in developed countries than when sold in emerging countries, after trickle-down. Hence, trickle-down can be interpreted as a form of priceskimming (Spann et al. 2015) on a supra-national basis. A high price is set in the early phases of the product life-cycle when targeting a narrow group of low-price-sensitivity consumers (i.e., developed countries), which is subsequently lowered to target a wider fraction of high-price-sensitivity consumers (i.e., emerging countries, as, today, $85 \%$ of the world population lives in emerging countries, Lagarde 2016). Reverse innovations have a higher price ( 2.50 versus $1.64, \mathrm{t}=25.42, p<0.01)$ and more attributes $(1.93$ versus
$1.40, \mathrm{t}=17.96, p<0.01)$ when sold in developed countries, after reverse innovation, than in emerging ones.

Products that eventually experience trickle-down were launched in more developed countries, before trickle-down, than products that eventually do not experience trickle-down (1.54 versus $1.14, \mathrm{t}=-22.82, p<0.01)$. Similarly, products that eventually experience reverse innovation were launched in more emerging countries, before reverse innovation, than products that eventually do not experience reverse innovation ( 1.36 versus $1.08, \mathrm{t}=-18.83, p<0.01)$.

MNCs are responsible for $21 \%$ of launches, $26 \%$ of trickledowns, and $28 \%$ of reverse innovations. Only $15 \%$ of products that experience trickle-down are launched for the first time in emerging countries by the same firm that originally launched them in a developed country. Similarly, only $13 \%$ of products that experience reverse innovation are launched for the first time in developed countries by the same firm that originally launched them in an emerging country.

\section{Hazard models analysis}

We run hazard models to test our hypotheses. We estimate three hazard models: (1) a model with time-invariant covariates, where price and number of attributes are averaged across launches for the same product before trickle-down (reverse innovation) or right-censoring, number of previous countries is the cumulative number of developed (emerging) countries in which the product has been launched before trickle-down (reverse innovation) or right-censoring, and multinationality takes on a value of 1 if the first firm to ever launch the product in a developed (emerging) country is a multinational, 0 otherwise; (2) a model with time-varying covariates, where we use the price, number of attributes, number of previous countries, and multinationality of the launching firm associated with consecutive launches to track the evolution of the product in the market over time; and (3) a model with time-varying covariates and a shared frailty term at the product-level to allow for intra-product correlation across launches. Figure 2 provides a graphical explanation of the difference between (1) and (2).

Endogeneity issues Before discussing our hazard models, we discuss possible biases in our results due to endogeneity. Specifically, we identify two potential sources of endogeneity. First, time effects may affect the speed at which products are launched in emerging (developed) countries. For instance, there might be years during which consumers in emerging (developed) countries are particularly open to products from developed (emerging) countries. During these years products might experience a faster trickle-down (reverse innovation). If this were the case, then time effects, rather than price, number of attributes, number of previous countries, and multinationality of the launching firm, would, at least partially, drive time to trickle- 
New Product $i \quad$ Launch 1
Launch 2

Japan

USA

October $16^{\text {th }} 2006$

|
Launch 3

UK
Launch 4

\section{India \\ India}

December $12^{\text {th }} 2007$

Model 1

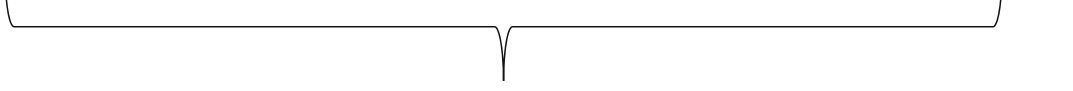

Time to Trickle-down

- Failure indicator equal to 1;

- Price and Number of Attributes are the average of Price and Number of Attributes in the USA, Japan, and the UK;

- Number of Previous Countries equal to 3 (USA, Japan, $U K)$;

- Multinationality takes on a value of 1 if the firm that launches the product in the USA is an MNC.

\begin{tabular}{|c|c|c|}
\hline $\begin{array}{l}\text { Time to Trickle-down } \\
\text { - } \quad \text { Failure indicator equal to 0; } \\
\text { Price and Number of } \\
\text { Attributes are Price and } \\
\text { Number of Attributes in the } \\
\text { USA; } \\
\text { - Number of Previous } \\
\text { Countries equal to } 1 \text { (USA); } \\
\text { Multinationality takes on a } \\
\text { value of } 1 \text { if the firm that } \\
\text { launches the product in the } \\
\text { USA is an MNC. }\end{array}$ & $\begin{array}{l}\text { Time to Trickle-down } \\
\text { - } \quad \text { Failure indicator equal to 0; } \\
\text { Price and Number of } \\
\text { Attributes are Price and } \\
\text { Number of Attributes in } \\
\text { Japan; } \\
\text { - Number of Previous Countries } \\
\text { equal to } 2 \text { (USA, Japan); } \\
\text { Multinationality takes on a } \\
\text { value of } 1 \text { if the firm that } \\
\text { launches the product in Japan } \\
\text { is an MNC. }\end{array}$ & $\begin{array}{l}\text { Time to Trickle-down } \\
\text { - } \quad \text { Failure indicator equal to 1; } \\
\text { Price and Number of } \\
\text { Attributes are Price and } \\
\text { Number of Attributes in the } \\
\text { UK; } \\
\text { - Number of Previous } \\
\text { Countries equal to } 3 \text { (USA, } \\
\text { Japan, UK); } \\
\text { Multinationality takes on a } \\
\text { value of } 1 \text { if the firm that } \\
\text { launches the product in the } \\
\text { UK is an MNC. }\end{array}$ \\
\hline
\end{tabular}

Model 2

Fig. 2 Graphical overview of the hazard models analysis

down (reverse innovation). To control for unobserved time effects, we include year fixed effects.

Second, consumers in emerging (developed) countries might be more open to new products that have been launched in a specific developed (emerging) country. To control for unobserved country effects, we include country fixed effects.

Further, one may argue that some unobserved firm-level considerations might drive both the price and number of attributes of new products at trickle-down (reverse innovation) and time to trickle-down (reverse innovation), as the firm that launches the product also sets its characteristics, i.e., price and number of attributes, in the new country. However, this is not a concern because we do not consider the price and number of attributes that products take on at trickle-down (reverse innovation) but rather their price and number of attributes before trickle-down (reverse innovation). Hence, there is no endogeneity as the firm that launches the product in the new country is not necessarily the same firm that set its characteristics in other countries. Similar considerations hold for the number of previous countries in which a product has been launched and for the multinationality of the launching firm.

Finally, one may argue that the launch sequence of a new product before trickle-down (reverse innovation) might be endogenous to the firm that decides to launch the product for the first time in an emerging (developed) country. However, as other firms are mostly responsible for the launch of the product in other countries, the launch sequence is exogenous to the focal firm. It is, however, worth-mentioning that, in Web Appendix D, we run a robustness analysis (see Table WD6) excluding new products that were launched more than once in developed (emerging) countries before experiencing trickle-down (reverse innovation) or right-censoring. For these new products, the dummy variable for the first country of launch fully accounts for the potential endogeneity of the sequence. The results, which are consistent with those of the main model, which we detail later, increase our confidence that potential launch sequence endogeneity does not bias our findings.

Hazard models with time-invariant covariates We present two models. Model $1_{\mathrm{A}}$ in Column 1 of Table 3 compares developed-only and trickle-down products. Both types of products are first launched in developed countries; the latter are eventually launched in emerging countries. Model $1_{B}$ in Column 1 of Table 4 compares emerging-only and reverse innovations. Both types of products are first launched in 
Table 3 Results of the hazard models analysis: Trickle-down

$\begin{array}{llll}\text { Model 1 } & \text { Model 2 } & \text { Model 3 } & \text { Model 4 }\end{array}$

DV: Hazard Rate of Trickle-down

\begin{tabular}{llll}
\hline Column 1 & Column 2 & Column 3 & Column 4 \\
Unstandardized & Unstandardized & Unstandardized & Unstandardized \\
coefficients (SE) & coefficients (SE) & coefficients (SE) & coefficients (SE)
\end{tabular}

\section{Price}

Number of Attributes

Previous Countries

Multinational

Price * Previous Countries

Number of Attributes * Previous Countries

Price * Multinational

Number of Attributes * Multinational

Control Variables

Product-level

Package Size

Previous Launches

Previous Countries Sharing Borders

Previous Countries Sharing Language

Firm-level

Category Experience ${ }^{\dagger}$

Experience in Developed Countries ${ }^{\dagger}$

Experience in Emerging Countries ${ }^{\dagger}$

Country-level

Small Market

Competition $^{\dagger}$

Year Fixed Effects

Country Fixed Effects

Observations

$\chi^{2}$

$* p<.10 . * * p<.05 . * * * p<.01$. All regressions include a constant. ${ }^{\dagger}$ Coefficient $\times 10^{2}$

$-.001(.01)$

$.01(.02)$

$.06(.05)$

$.31(.05)^{* * * *}$

$-.03(.02)$

$.01(.02)$

$.03(.04)$

$-.17(.15)$

$-.02(.01)^{*}$

YES

YES

YES

YES

43,052

756.65

$\begin{array}{lll}-.03(.01)^{* * *} & -.04(.01)^{* * *} & -.04(.01)^{* * *} \\ -.01(.01) & .005(.01) & -.01(.01) \\ .27(.08)^{* * * *} & .71(.08)^{* * * *} & .74(.09)^{* * *} \\ .29(.06)^{* * * *} & .42(.07)^{* * * *} & .19(.10)^{* *} \\ & & -.01(.01) \\ & -.01(.01) \\ & .06(.02)^{* *} \\ & .04(.02)^{* *}\end{array}$

$.004(.003)$

$-.02(.06)$

$.16(.07)^{* * *}$

$.36(.06) * * *$

$.001(.01)$

$30(.05) * * *$

$.08(.08)$

$.22(.08) * * *$

$.001(.01)$

$.29(.05)^{* * * *}$

$.08(.08)$

$.22(.08) * * *$

$-.03(.02)^{*}$

$.02(.02)$

$.03(.03)$

$-.03(.02)$

$-.01(.02)$

$-.02(.02)$

$-.01(.02)$

$.05(.03)$

$.03(.03)$

$-.11(.15)$

$-.01(.01)$

$-.14(.18)$

$-.13(.18)$

$-.01(.01)$

YES

YES

YES

43,052

43,052

1935.82 emerging countries; the latter are eventually launched in developed countries.

Because our data are right-censored, i.e., not all products experience trickle-down (reverse innovation) by the end of our observation period, we cannot use standard regression. Hence, consistent with the literature on international new product launch speed (Danzon et al. 2005), we use a proportional hazard model, which allows for right-censored observations. The dependent variable is made up of two parts: (1) the time to event, i.e., time to trickle-down or reverse innovation; and (2) the event status, which records if the event of interest has occurred or not at a certain date. For the sake of simplicity, we present Model $1_{\mathrm{A}}$ only (See Column 1 of Table 3 ). The failure indicator takes on a value of 1 if the new product initially launched in a developed country is eventually launched in an emerging country and 0 if the new product is right-censored. We treat the product's price and number of attributes as timeinvariant and average them (as well as package size) across all launches before trickle-down or right-censoring. Further, the number of previous countries is the total number of developed countries in which the product has been launched before trickle- down or right-censoring. Finally, the multinationality indicator takes on a value of 1 if the first firm to ever launch the product in a developed country is an MNC; 0 otherwise (please see Fig. 2).

We use a Weibull distribution, which is suitable for modeling data with monotone hazard rates, which can be written as:

$$
\begin{aligned}
h\left(t_{i}\right) & =h_{0}(\mathrm{t}) \exp \left(\beta_{0}+\beta_{1} \text { Price }_{i}+\beta_{2} \text { Number Attributes }_{i}\right. \\
& +\beta_{3} \text { Previous Countries }_{i}+\beta_{4} \text { Multinational }_{i} \\
& +\sum_{f=5}^{8} \beta_{f} \text { PDT }_{i}+\sum_{f=9}^{11} \beta_{f} \text { FIRM }_{i}+\sum_{f=12}^{13} \beta_{f} \\
& \text { COUNTRY } \left._{i}+\text { Country FES }+ \text { Year FEs }+\varepsilon_{A i}\right)
\end{aligned}
$$

where $h\left(t_{i}\right)$ is the hazard rate of trickle-down (reverse innovation) for product $i$ at time $t, \beta \mathrm{s}$ are the parameters to be estimated, and $\varepsilon_{A i}$ s represent error terms. PDT represents productlevel control variables (i.e., package size, number of previous launches, number of previous countries sharing borders, number of previous countries sharing a common official language), FIRM represents firm-level control variables (i.e., category experience, experience in developed countries, and experience in emerging countries), and COUNTRY represents 
Table 4 Results of the hazard models analysis: Reverse innovation

$\begin{array}{llll}\text { Model } 1_{\mathrm{B}} & \text { Model 2 } & \text { Model } 3_{\mathrm{B}} & \text { Model 4 }\end{array}$

DV: Hazard Rate of Reverse Innovation

\begin{tabular}{llll}
\hline Column 1 & Column 2 & Column 3 & Column 4 \\
Unstandardized & Unstandardized & Unstandardized & Unstandardized \\
coefficients (SE) & coefficients (SE) & coefficients (SE) & coefficients (SE)
\end{tabular}

\section{Price}

Number of Attributes

Previous Countries

Multinational

Price * Previous Countries

Number of Attributes * Previous Countries

Price * Multinational

Number of Attributes * Multinational

Control Variables

Product-level

Package Size

Previous Launches

Previous Countries Sharing Borders

Previous Countries Sharing Language

Firm-level

Category Experience ${ }^{\dagger}$

Experience in Developed Countries ${ }^{\dagger}$

Experience in Emerging Countries ${ }^{\dagger}$

Country-level

Small Market

Competition $^{\dagger}$

Year Fixed Effects

Country Fixed Effects

Observations

$x^{2}$

$* \mathrm{p}<.10 . * * \mathrm{p}<.05 . * * * \mathrm{p}<.01$. All regressions include a constant. ${ }^{\dagger}$ Coefficient $\times 10^{2}$

$.03(.01)^{* * * *}$
$.06(.01)^{* * *}$
$.61(.05)^{* * * *}$
$.36(.07)^{* * * *}$

$.02(.005)^{* * *}$

$06(.01)^{* * * *}$

$29(.04)^{* * * *}$

$.27(.07)^{* * * *}$
$.09(.01) * * *$
$.08(.01) * * *$
$.94(.07) * * *$
$.44(.08) * * *$
$.11(.01)^{* * * *}$

$.08(.02)^{* * * *}$

$1.01(.07)^{* * * *}$

$.48(.10)^{* * * *}$

$-.02(.01)$

$-.04(.02) * *$

$-.06(.03)^{* * *}$

$.04(.02)$

$$
\begin{aligned}
& -.04(.01)^{* * *} \\
& .07(.02)^{* * *} \\
& .35(.09)^{* * *} \\
& -.02(.09)
\end{aligned}
$$

$$
\begin{aligned}
& -.02(.02) \\
& .08(.03)^{* * *} \\
& -.12(.04)^{* * *}
\end{aligned}
$$
$-.23(.41)$
$-.01(.01)$
YES

YES

25,977

25,977
708.71
$.01(.02)$

$.06(.03)^{* * *}$

$-.13(.03)^{* * * *}$

$-.04(.34)$

$-.005(.01)$

YES

YES

37,295

1345.10
$-.0003(.02)$

$.07(.03)^{* *}$

$.01(.38)$

$-.01(.01)$

YES

YES

37,295

1450.43
$-.14(.04)^{* * *}$
$-.04(.01)^{* * * *}$ $.06(.02) * * *$ $.33(.09)^{* * *}$ -.003 (.08)

$.002(.02)$

$.07(.03)^{* * *}$

$-.14(.04) * * *$

.005 (.38)

$-.01(.01)$

YES

YES

37,295

1463.19 country-level control variables (i.e., small market and competition). $h_{0}(\mathrm{t})$ is the baseline hazard function that, once multiplied by $\exp \left(\beta_{0}\right)$, reflects the hazard of the outcome occurring for those products whose covariates equal 0 , and it takes the form $h_{0}(\mathrm{t})=v \mathrm{t}^{v-1}$ where $v>0$ is a shape parameter to be estimated from the data. If $v>1$, then the hazard rate increases over time, while if $v<1$, the hazard rate decreases over time. We test the model in Eq. 1 and provide results in the no-hazard rates metric, presenting coefficients rather than exponentiated coefficients. Positive $b$ coefficients increase the speed of trickle-down (Model $1_{\mathrm{A}}$ ) or reverse innovation (Model $1_{\mathrm{B}}$ ) while negative $b$ coefficients decrease the speed of trickledown $\left(\right.$ Model $1_{\mathrm{A}}$ ) or reverse innovation (Model $1_{\mathrm{B}}$ ).

We report the results for trickle-down and reverse innovation in Column 1 of Tables 3 and 4, respectively. An increase in price decelerates trickle-down $(\mathrm{b}=-0.03, p<0.01)$ in support of H1a, while accelerating reverse innovation $(\mathrm{b}=0.02, p<$ 0.01 ), in support of H1b. The number of attributes has no effect on the hazard rate of trickle-down $(\mathrm{b}=-0.01, p>0.10)$. Hence, $\mathrm{H} 2 \mathrm{a}$ is not supported. An increase in the number of attributes accelerates reverse innovation $(b=0.06, p<0.01)$ in support of
$\mathrm{H} 2 \mathrm{~b}$. An increase in the number of developed countries in which the product has been launched increases the hazard rate of trickle-down $(b=0.09, p<0.05)$ in support of H3a. Similarly, an increase in the number of emerging countries in which the product has been launched increases the hazard rate of reverse innovation $(b=0.29, p<0.01)$ in support of $\mathrm{H} 3 \mathrm{~b}$. Finally, having been launched by an MNC increases the speed of both trickle-down $(\mathrm{b}=0.26, p<0.01)$ and reverse innovation ( $\mathrm{b}=0.27, p<0.01)$, in support of $\mathrm{H} 4 \mathrm{a}$ and $\mathrm{H} 4 \mathrm{~b}$.

With regard to product-level control variables, a larger package size $(b=-0.0003, p<0.01)$ and an increase in the number of previous launches in emerging countries decelerate reverse innovation $(\mathrm{b}=-0.02, p<0.05)$. An increase in the number of developed countries where the product has been launched that share a common official language with at least one emerging country accelerates trickle-down $(\mathrm{b}=0.31, p<0.01)$. An increase in the number of emerging countries where the product has been launched that share borders with at least one developed country accelerates reverse innovation $(b=0.23, p<0.01)$.

With regard to firm-level control variables, the launching firm's experience in developed countries accelerates reverse 
innovation $(\mathrm{b}=0.001, p<0.01)$, while its experience in emerging countries decelerates it $(b=-0.001, p<0.01)$.

Hazard models with time-varying covariates We now change our model to take into account the evolution of product characteristics, i.e., price, number of attributes, number of previous countries, and multinationality of the launching firm, over consecutive launches before trickle-down (reverse innovation) or right-censoring. Let $t_{k}$ be the time at which trickle-down (reverse innovation) or right-censoring occurs. Following Tellis et al. (2003), we divide $t_{k}$ into K non-overlapping time intervals, which can have different durations. Let $t_{0}$ be the initial launch date and $t_{0}<t_{1}<\ldots<t_{j-1}<t_{j}<\ldots<t_{k}$. Each time interval begins and ends when a new launch occurs. More specifically, when a launch occurs at $t_{0}$, its characteristics, i.e., price, number of attributes, number of previous countries, and multinationality of the launching firm, are assumed to persist until $t_{1}$, when a new launch occurs. Further, each time interval is associated with a failure indicator that takes on a value of 1 if, eventually, the product experiences trickle-down or reverse innovation; 0 otherwise. Hence, if product $i$ is launched at $t_{0}$ in the U.S., at $t_{1}$ in Japan, at $t_{2}$ in the U.K., and at $t_{3}$ in India, the failure indicator takes on a value of 0 in correspondence of the $t_{0}-t_{1}$ and the $t_{1}-t_{2}$ time intervals, as the product does not experience trickle-down at $t_{1}$ and $t_{2}$, and a value of 1 in correspondence of the $t_{2}-t_{3}$ time interval, because at the end of this period, at $t_{3}$, the product experiences trickle-down to India. When multiple launches for a given product occur on the same day, we retain only one observation and average its characteristics across those simultaneous launches. We estimate the following equation:

$$
\begin{gathered}
h\left(t_{i}\right)=h_{0}(\mathrm{t}) \exp \left(\mu_{0}+\mu_{1} \text { Price }_{i t}+\mu_{2} \text { Number Attributes }_{i t}+\right. \\
\mu_{3} \text { Previous Countries }_{i t}+\mu_{4} \text { Multinational }_{i t}+\sum_{f=5}^{8} \mu_{f} P D T_{i t}+ \\
\sum_{f=9}^{11} \mu_{f} \text { FIRM }_{i t}+\sum_{f=12}^{13} \mu_{f} \text { COUNTRY }_{i t}+\text { Country FEs } \\
\left.+ \text { Year FEs }+\varepsilon_{\text {Bit }}\right)
\end{gathered}
$$

where $h\left(t_{i}\right)$ is the hazard rate of trickle-down (reverse innovation) for product $i$ at time $t, h_{0}(\mathrm{t})$ is the baseline hazard rate, $\mu \mathrm{s}$ are the parameters to be estimated, and $\varepsilon_{B i t} \mathrm{~s}$ are error terms. PDT once again represents product-level control variables, FIRM represents firm-level control variables, and COUNTRY represents country-level control variables.

We estimate eq. 2 in Models 2 (Column 2 of Table 3 ) and $2_{\mathrm{B}}$ (Column 2 of Table 4 ) by assuming a Weibull distribution. We cluster launches at the product-level to account for possible correlation among errors across different launches for the same product.

In our data, launches are nested within products. Hence, in Models $3_{\mathrm{A}}$ (Column 3 of Table 3 ) and $3_{\mathrm{B}}$ (Column 3 of Table 4 ) we introduce a shared frailty term at the product-level to allow for intra-product correlation across launches. Across products, the frailties are assumed to be gamma-distributed unobserved random effects that act multiplicatively on the hazard rate. For each observation (i.e., launch) in each group (i.e., product), a shared frailty model introduces a random effect at the productlevel, modeled for the product and shared by all launches. In sum, both Models 2 and 3 account for the time windows across all the launches for a product before trickle-down (reverse innovation) or right-censoring. Model 3 moves one step forward by introducing the shared frailty term.

For reasons of brevity and as results are consistent across Models 2 and 3, we comment on the results of Models $3_{\mathrm{A}}$ and $3_{\mathrm{B}}$ (See Column 3 of Tables 3 and 4, respectively) only as they are characterized by slightly lower AIC and BIC. Both Models $3_{\mathrm{A}}$ and $3_{\mathrm{B}}$ are significant $\left(\chi_{a}^{2}=1923.93, p<0.01\right.$ and $\chi_{b}^{2}=$ $1450.43, p<0.01)$. The ancillary parameters $\left(v_{\mathrm{a}}=0.93\right.$ and $v$ $\mathrm{b}=0.90)$ indicate that the hazard rates decrease over time, i.e., the longer the product has been in the market without experiencing trickle-down (reverse innovation), the lower its chances will be of doing so in the future. In both cases, we find a significant frailty effect, meaning that the correlation within products cannot be ignored $\left(\theta_{\mathrm{a}}=3.75, p<0.01\right.$ and $\left.\theta_{\mathrm{b}}=2.51, p<0.01\right)$. An increase in price decelerates trickle-down $(\mathrm{b}=-0.04, p<0.01)$ in support of H1a while accelerating reverse innovation $(\mathrm{b}=0.09, p$ $<0.01)$ in support of H1b. To facilitate the interpretation of the estimated coefficients, we determine, through the transformation $100\left(e^{b}-1\right)$, the percentage change in the expected hazard rate for a one-unit increase in the focal variable. Thus, $100\left(e^{-0.04}-1\right)=$ $-3.92 \%$ indicates the percentage decrease in the hazard rate of trickle-down for each one-unit increase in price, holding the other regressors constant, while a unitary increase in price increases the hazard rate of reverse innovation by $9.42 \%$. An increase in the number of attributes has no effect on trickle-down $(b=0.005$, $p>0.10$ ) against $\mathrm{H} 2 \mathrm{a}$, while it significantly accelerates reverse innovation $(\mathrm{b}=0.08, p<0.01)$ in support of $\mathrm{H} 2 \mathrm{~b}$ : an additional attribute increases the hazard rate of reverse innovation by $8.33 \%$. An increase in the number of developed countries in which the product has been launched increases the hazard rate of trickle-down $(\mathrm{b}=0.71, p<0.01)$ in support of H3a: an additional country increases the hazard rate of trickle-down by $103.40 \%$. Similarly, an increase in the number of emerging countries in which the product has been launched increases the hazard rate of reverse innovation $(b=0.94, p<0.01)$ in support of $\mathrm{H} 3 \mathrm{~b}$ : an additional country increases the hazard rate of reverse innovation by $156 \%$. Finally, having been launched by an MNC accelerates both trickle-down $(b=0.42, p<0.01)$ and reverse innovation $(\mathrm{b}=0.44, p<0.01)$ in support of $\mathrm{H} 4 \mathrm{a}$ and $\mathrm{H} 4 \mathrm{~b}$ : having been launched by an $\mathrm{MNC}$ increases the hazard rate of trickle-down by $52.20 \%$ and the hazard rate of reverse innovation by $55.27 \%$.

With regard to product-level control variables, an increase in package size decelerates reverse innovation $(b=-0.0004, p<$ $0.01)$. An increase in the number of previous launches $(b=$ $0.30, \mathrm{p}<0.01$ ) and an increase in the number of previous developed countries where the product has been launched that share a 
common official language with at least one emerging country $(\mathrm{b}=0.22, p<0.01)$ accelerate trickle-down. An increase in the number of previous launches $(b=0.07, p<0.01)$ and an increase in the number of previous emerging countries where the product has been launched that share borders with at least one developed country $(\mathrm{b}=0.35, p<0.01)$ accelerate reverse innovation.

With regard to firm-level control variables, an increase in the launching firm's experience in developed countries accelerates reverse innovation $(b=0.001, p<0.05)$, while an increase in the launching firm's experience in emerging countries decelerates it $(\mathrm{b}=-0.001, p<0.01)$.

\section{Additional analysis: Interaction effects}

We now run an additional analysis including the interaction terms of product price and number of attributes with the number of previous countries and multinationality of the launching firm (Models $4_{\mathrm{A}}$ and $4_{\mathrm{B}}$ ). We report the results in Column 4 in Tables 3 and 4, respectively. The results for the main effects are consistent with those obtained in Models $3_{\mathrm{A}}$ and $3_{\mathrm{B}}$.

Model $4_{\mathrm{A}}$ shows that the positive effect of multinationality on the hazard rate of trickle-down is strengthened when product price $(\mathrm{b}=0.06, p<0.05)$ or number of attributes $(\mathrm{b}=0.04, p<$ 0.05 ) increase. Model $4_{B}$ shows that the positive effect of number of attributes on the hazard rate of reverse innovation is weakened when the product has been launched in numerous emerging countries $(\mathrm{b}=-0.04, p<0.05)$ and that the positive effect of multinationality on the hazard rate of reverse innovation is weakened when price increases $(b=-0.06, p<0.05)$.

We interpret these results as follows. According to Kalish et al. (1995), potential consumers in lag countries observe the product in lead countries and this reduces the perceived risk associated with purchase. Hence, products that have been launched in numerous countries before being launched in the focal country are perceived as less risky by consumers. Coherently, the positive effect of number of attributes on the hazard rate of reverse innovation is weakened when the product has been launched in numerous emerging countries as consumers in developed countries, who use the number of attributes of a product as guarantee of its quality (see H2b), will depend less on the number of attributes of the product to assess its quality level. Similarly, as already mentioned, the imitation of MNCs' new products by competitors often occurs for purposes of risk minimization (Head et al. 2002; Ordanini et al. 2008). It stands to reason that this effect may become stronger when products that might be launched for the first time in emerging (developed) countries differ from the expectations of consumers in emerging (developed) countries. In this case, imitators may be even more likely to imitate new products launched by MNCs as a way to reduce the risks associated with trickle-down (reverse innovation). Coherently, the effect of multinationality on the hazard rate of trickle-down is strengthened when products to be launched in emerging countries have a higher price or many attributes (See our argumentations for $\mathrm{H} 1 \mathrm{a}$ and H2a). Finally, the effect of multinationality on the hazard rate of reverse innovation is weakened when products to be launched in developed countries have a higher price, i.e., are more suited to the expectations of consumers in developed countries (See our argumentations for H1b).

Hazard models: Robustness checks Our results are robust to sampling variations, alternative distributional assumptions, and alternative measures. For detailed robustness analyses, see Web Appendix D.

\section{Performance implications of the speed of trickle-down and reverse innovation}

We now investigate whether the speed of trickle-down (reverse innovation) influences the performance of new products after they experience trickle-down (reverse innovation). Unfortunately, there are no sales data available to measure performance. Hence, building on the literature on export performance, which, as shown by Katsikeas et al. (2000), has used the number of export countries to measure success, we measure the performance of a trickle-down product using the number of launches in emerging countries after trickle-down. We reason that if a new product is successful, many firms will try to imitate it and, hence, we will observe many launches. Our dependent variable is thus the average number of launches in emerging countries for the product in a year after trickle-down. We obtain this variable as follows: (1) for each new product we count the overall number of launches in emerging countries after trickledown; (2) we divide this number by the number of days elapsing between trickle-down and the end of our data collection period, i.e., December $31^{\text {st }} 2014$, to obtain the average number of launches in emerging countries for the product in a day; and (3) we finally multiply the obtained number by 365 to obtain the average number of launches in emerging countries for the product in a year and take the natural logarithm - after having added 1.00 - to facilitate the interpretation of the results.

Our data may suffer from selection bias as it may be that, among those products initially launched in developed countries, only the best ones experience trickle-down. Superior quality may also influence subsequent performance. Hence, we employ a Heckman's two-step sample selection model. In the firststage, we predict a product's individual probability to experience trickle-down by using the same covariates employed in Model $1_{\mathrm{A}}$. We then compute the Inverse Mills ratio and, to correct for selection bias, add it in the second-stage to estimate the impact of time to trickle-down on performance (Model $5_{\mathrm{A}}$ ). We proceed analogously for reverse innovations (Model $5_{\mathrm{B}}$ ).

The results are reported in Columns $1-4$ of Table 5 . The estimated selection coefficient is significant in both Models $5_{\mathrm{A}}$ $(\lambda=-0.17, p<0.01)$ and $5_{\mathrm{B}}(\lambda=-0.16, p<0.01)$, indicating that we are correcting for selection bias. 
Table 5 Results of the Heckman's sample selection model

\begin{tabular}{|c|c|c|c|c|}
\hline & \multicolumn{2}{|l|}{ Model $5_{\mathrm{A}}$} & \multicolumn{2}{|l|}{ Model $5_{\mathrm{B}}$} \\
\hline & $\begin{array}{l}\text { DV: Performance in } \\
\text { Emerging Countries } \\
\text { Column } 1 \\
\text { Unstandardized } \\
\text { coefficients (SE) }\end{array}$ & $\begin{array}{l}\text { DV: Likelihood } \\
\text { of Trickle-down } \\
\text { Column } 2 \\
\text { Unstandardized } \\
\text { coefficients (SE) }\end{array}$ & $\begin{array}{l}\text { DV: Performance in } \\
\text { Developed Countries } \\
\text { Column } 3 \\
\text { Unstandardized } \\
\text { coefficients (SE) }\end{array}$ & $\begin{array}{l}\text { DV: Likelihood of } \\
\text { Reverse Innovation } \\
\text { Column } 4 \\
\text { Unstandardized } \\
\text { coefficients (SE) }\end{array}$ \\
\hline Time to Trickle-down ${ }^{\dagger}$ & $-.003(.001)^{* * *}$ & & & \\
\hline Time to Reverse Innovation ${ }^{\dagger}$ & & & $-.005(.001)^{* * *}$ & \\
\hline Price & & $-.02(.005)^{* * *}$ & & $.03(.01)^{* * *}$ \\
\hline Number of Attributes & & $-.01(.01)$ & & $.03(.01)^{* * *}$ \\
\hline Previous Countries & & $.13(.03)^{* * *}$ & & $.27(.03)^{* * *}$ \\
\hline Multinational & & $.16(.03)^{* * *}$ & & $.20(.04)^{* * *}$ \\
\hline \multicolumn{5}{|l|}{ Control Variables } \\
\hline \multicolumn{5}{|l|}{ Product-level } \\
\hline Package Size ${ }^{\dagger}$ & & $-.0001(.003)$ & & $-.02(.01)^{* * *}$ \\
\hline Previous Launches & & $.03(.01)^{* *}$ & & $-.01(.01)^{*}$ \\
\hline Previous Countries Sharing Borders & & $-.002(.04)$ & & $.16(.06)^{* * *}$ \\
\hline Previous Countries Sharing Language & & $.20(.03)^{* * *}$ & & $.07(.05)$ \\
\hline \multicolumn{5}{|l|}{ Firm-level } \\
\hline Category Experience $^{\dagger}$ & & $-.01(.01)$ & & $-.01(.01)$ \\
\hline Experience in Developed Countries ${ }^{\dagger}$ & & $.005(.01)$ & & $.04(.01)^{* *}$ \\
\hline Experience in Emerging Countries ${ }^{\dagger}$ & & $.02(.02)$ & & $-.06(.02)^{* * *}$ \\
\hline \multicolumn{5}{|l|}{ Country-level } \\
\hline Small Market & & $-.10(.09)$ & & $-.17(.19)$ \\
\hline Competition $^{\dagger}$ & & $-.01(.004)^{* *}$ & & $.0005(.004)$ \\
\hline Year Fixed Effects & YES & YES & YES & YES \\
\hline Country Fixed Effects & YES & YES & YES & YES \\
\hline $\begin{array}{l}\text { Observations } \\
\chi^{2}\end{array}$ & $\begin{array}{l}33,241 \\
179.66\end{array}$ & & $\begin{array}{l}25,987 \\
177.30\end{array}$ & \\
\hline
\end{tabular}

$* \mathrm{p}<.10 . * * \mathrm{p}<.05 . * * * \mathrm{p}<.01$. All regressions include a constant. ${ }^{\dagger}$ Coefficient $\times 10^{2}$

The results of the first-stage equations are consistent with the results of our hazard models. An increase in price decreases the probability of trickle-down $(\mathrm{b}=-0.02, p<0.01)$ while increasing the probability of reverse innovation $(\mathrm{b}=0.03, p<0.01)$. An increase in the number of attributes has no effect on the probability of trickle-down $(\mathrm{b}=-0.01, p>0.10)$, while it significantly increases the probability of reverse innovation $(b=0.03, p<$ $0.01)$. Further, an increase in the number of developed countries where the product has been launched increases the probability of trickle-down $(\mathrm{b}=0.13, p<0.01)$. Similarly, an increase in the number of emerging countries where the product has been launched increases the probability of reverse innovation $(b=$ $0.27, p<0.01)$. Finally, having been launched by an MNC increases the probability of trickle-down $(b=0.16, p<0.01)$ and reverse innovation $(b=0.20, p<0.01)$. For the second-stage equations, Model $5_{\mathrm{A}}$ shows that time to trickle-down has a negative effect on performance $(b=-0.00003, p<0.01)$. Model $5_{\mathrm{B}}$ shows that time to reverse innovation has a negative effect on performance $(b=-0.00005, p<0.01)$. Hence, we show that fast is indeed better and that products that experience a faster trickle-down (reverse innovation) experience greater success, after controlling for the fact that only products with certain characteristics experience trickle-down (reverse innovation).

\section{Discussion}

International new product launch speed is a crucial goal for firms (Verniers et al. 2011; Yeniyurt et al. 2007). However, the current literature presents several theoretical and empirical gaps that seriously limit our understanding of this topic. We have highlighted two specific issues: (1) the rising importance 
of emerging countries, with the correlated difficulties for Western MNCs in launching products in these countries, and (2) the rising competitive threat from emerging countries' firms. In order to gain a deeper understanding of this competitive scenario, we combined four streams of literature to develop a comprehensive theoretical framework of the antecedents of the speed of two specific types of international new product launch: trickle-down and reverse innovation. We tested this framework in an extensive dataset including many emerging countries and many small local firms.

Our main goal was to offer a more realistic picture of the complexities that characterize today's global marketplace by providing the first large-scale assessment of how new products move from developed countries to emerging ones and vice versa. Since the previous literature on this topic has always been limited to a few, qualitative cases (see e.g., Govindarajan and Trimble 2012; Govindarajan and Trimble 2011), we believe that quantitatively documenting which characteristics of a new product affect its speed of trickledown (reverse innovation) has great value for academics and managers, who, so far, have scant and anecdotal knowledge about these issues. We now discuss the theoretical and managerial contributions of our work more in detail.

\section{Theoretical contributions}

First, we make a novel extension to the limited literature on the antecedents of international new product launch speed, which has hitherto focused on firm- and country-level antecedents. Differently, we focus on marketing-mix elements, i.e., price and number of attributes. By investigating the antecedents of trickle-down and reverse innovation, we further add to the literature on international new product launch speed, which to date has neglected the differences between emerging and developed countries (Sheth 2011).

Second, we are the first to empirically examine the characteristics of products that accelerate trickle-down and reverse innovation in a large quantitative study. Thus, we contribute to the literature on innovation for and from emerging countries, which to date has been largely anecdotal (Ernst et al. 2015). By showing that a higher price decelerates trickle-down, while a higher price and number of attributes accelerate reverse innovation, we show that the same marketing mix element may display opposite effects in developed and emerging countries.

Third, by examining the history of past launches of the product, our results fill another gap in the literature on international new product launch speed, which has thus far considered international new product launches in isolation. At the same time, our results also add to the literature on innovation diffusion and adoption in the global marketplace by showing that crosscountry learning effects influence not only the performance of new products in specific countries but also the speed at which new products are launched in different countries.
Fourth, by showing that new products launched by MNCs experience a faster trickle-down (reverse innovation) as a result of imitation, our results further add to the literature on international new product launch speed, which has always acted under the assumption that it is the same firm to launch the product across different countries. Our results answer a recent call to conduct additional research on imitation of new products in today's global marketplace (Shinkle and McCann 2014). By focusing on cross-country imitation in both emerging and developed countries, we extend the mainstream literature on imitation, which to date has focused on within-country imitation in emerging countries.

Fifth, we explore the interaction effects of product price and number of attributes with the number of previous countries in which the product has been launched and multinationality of the launching firm. Such results extend extant findings in the literatures on innovation diffusion and adoption and imitation in the global marketplace. In particular, they corroborate the relevance of the number of previous countries in which a product has been launched and of the multinationality of the launching firm in reducing the perceived risk associated with the new product by consumers and imitators.

Finally, by showing that the speed at which trickledown and reverse innovation occur significantly affects product performance (see Table 5), our study empirically establishes a linkage between international new product launch speed and performance. In doing so, it corroborates the relevance of our findings by making it clear that knowing what accelerates trickle-down (reverse innovation) is a crucial takeaway for researchers in the international business area.

\section{Managerial implications}

From a managerial perspective, the findings generate actionable implications for managers of both MNCs and local firms. Collectively, our findings may help managers (1) modify existing new products to enter foreign markets more quickly, (2) forecast which new products will enter domestic markets more quickly, (3) identify which of their new products are particularly susceptible to foreign imitation.

First, for firms wishing to expand into foreign markets, the practical finding from this study is that firms should adapt their marketing mix when targeting emerging versus developed countries (Bahadir et al. 2015). In other words, to unlock additional sources of cash flows and profits by opening up new markets for their new products, firms need to carefully manage traditional marketing levers, i.e., price and number of attributes, tailoring their decisions to whether the country that they are targeting is developed or emerging. 
Second, on the other side of the coin, for firms wishing to defend their established positions in domestic markets, the results imply that low-priced products can be expected to enter emerging countries faster. They also imply that products with higher prices and more attributes can be expected to enter developed countries faster. Further, products that have been launched in more developed (emerging) countries and/or have been launched by MNCs (versus not) can be expected to enter emerging (developed) countries faster. These findings may help firms anticipate competitors' moves for purposes of spatial preemption.

Third, our findings may help firms understand which of their new products are particularly susceptible to foreign imitation. We replicated Models $3_{\mathrm{A}}$ and $3_{\mathrm{B}}$ excluding all subsequent launches by the firm that originally introduces the product and found the results to be consistent with those reported in the main model (see Columns 5 and 6 of Table WD4 in Web Appendix D). As our results hold even when excluding subsequent launches by innovative firms, our study can safely be interpreted as a study of imitative processes. Hence, we can offer a further interpretation of our results, which is particularly relevant for managers of innovative firms. Our findings strike a cautionary note with regard to the products that experience a faster trickle-down (reverse innovation). Managers should in fact be aware that these products also experience a faster trickle-down (reverse innovation) as a result of imitation in foreign markets. As a consequence, our results have implications for managers in other low-IP industries such as fashion, banking, broadcasting, and telecommunications. Further, they also have implications for policymakers wishing to defend the exports of domestic MNCs, by signaling which products have a higher likelihood to be imitated abroad.

Finally, our results also show (see Table 5) that products that experience a faster trickle-down (reverse innovation) enjoy superior performance. This result confirms that achieving a fast new product launch is paramount in a global marketplace where about $95 \%$ of new products fail. ${ }^{7}$

\section{Limitations and directions for future research}

Although this study provides relevant insights, it has some limitations that should be considered fruitful avenues for future research.

First, the performance of a product in previous countries might influence the speed at which the product experiences trickle-down or reverse innovation. Unfortunately, given the extensiveness of our sample, we do not have

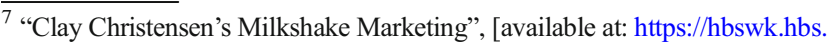
edu/item/clay-christensens-milkshake-marketing].
}

sales data at the product-level. These data are available just at the firm-level and for a subset of large firms. We believe that using firm-level sales data would introduce biases in our analyses, as we would limit our sample to the largest firms and attribute their performance to one specific product. Further, such large firms are typically firms from developed countries (88\% of the MNCs in our sample are from developed countries). Dropping almost all the observations pertaining to new products launched by emerging countries' firms would detract from the value of our contribution, which aims at providing a comprehensive overview of competitive dynamics in today's global marketplace, where emerging countries, as well as emerging countries' firms, play a crucial role. Finally, dropping launches by small firms from emerging countries would mistakenly alter the launch sequence of a new product and, therefore, its classification as trickledown/reverse innovation/developed-only/emerging-only. In other words, dropping observations due to the lack of sales data would result in an erroneous classification of products' launch patterns, the focus of our research. We therefore decided not to include firm-level sales data as a control variable in our model. However, we control for the number of times a product has been launched in countries of the initial type (e.g., developed) before the current date. We expect this variable to be a reasonable proxy of the product performance in previous countries, partially making up for the lack of sales data, as more successful products are launched by more firms (see Tellis et al. 2003 for a similar logic). Still, future research could benefit from the use of sales data at the product-level.

Second, our analysis is limited to one industry. While the packaged food industry has generated considerable interest (see e.g., Cillo et al. 2018; Sorescu and Spanjol 2008), empirical testing in other industries would be beneficial. Further, in the packaged food industry, different firms may launch the same product across different countries. While this has some advantages (i.e., endogeneity reduction, possibility to study imitation mechanisms), the generalizability of this research's findings beyond the food industry emerges as a potential issue.

Third, we do not have information on the location where new products were initially conceptualized and developed, but just on where they were launched (Von Zedtwitz et al. 2015). Acquiring information on the first two phases could help better understand the role of emerging countries in the global international new product launch process.

Acknowledgments The authors would like to thank the Special Issue Guest Editors and the three anonymous reviewers for their valuable comments and suggestions. 


\section{Appendix}

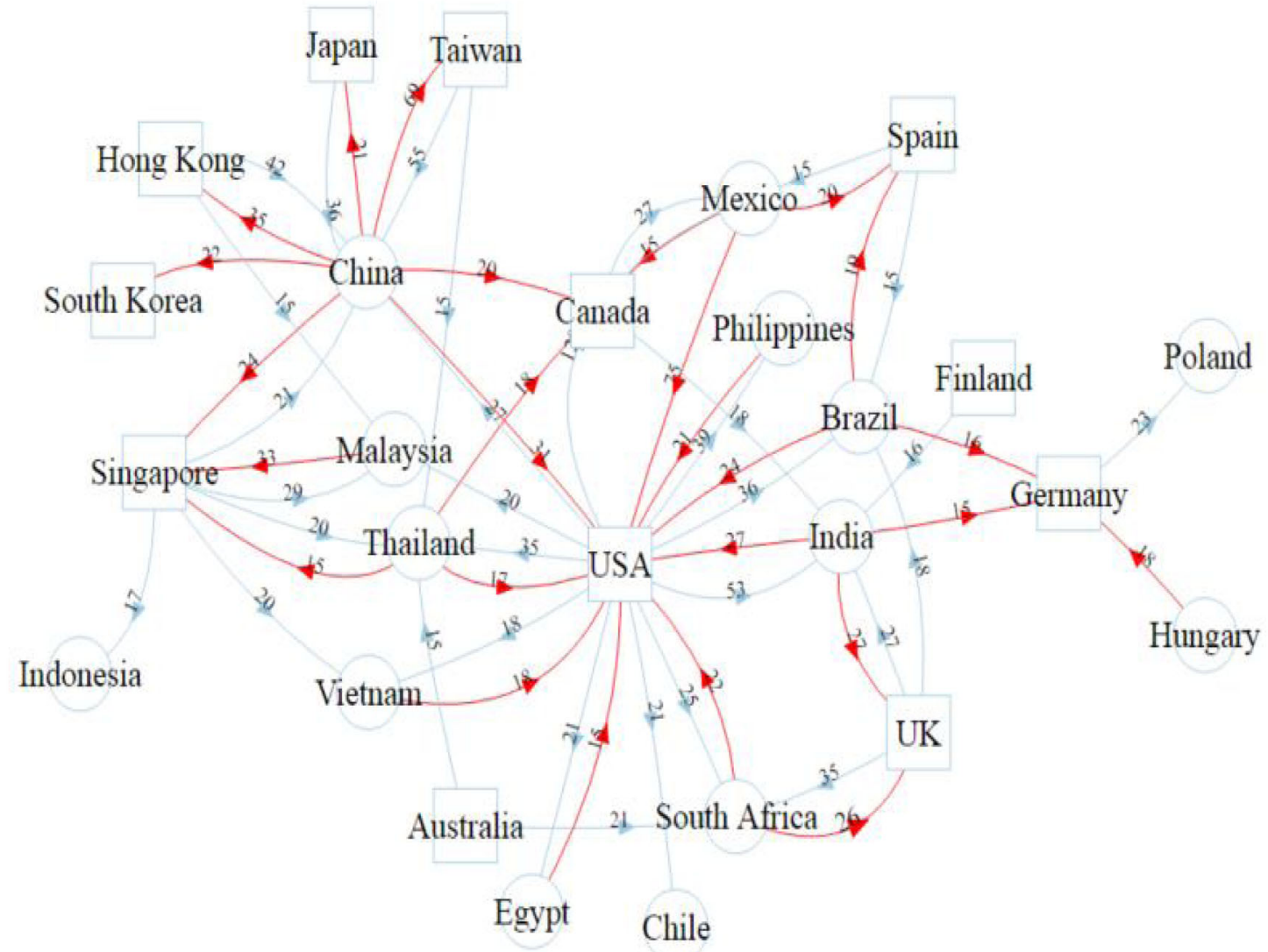

Fig. 3 Most common country sequences leading to trickle-down and reverse innovation. Notes: The red lines, connecting emerging countries (circles) to developed ones (squares), represent reverse innovations, while the blue lines, connecting developed countries to emerging ones, represent trickle-downs. The numbers indicate how many times the sequence occurs in the dataset 
Table 6 Descriptives and correlations: Trickle-down and developed-only

\begin{tabular}{|c|c|c|c|c|c|c|c|c|c|c|c|c|c|c|c|c|}
\hline & Mean & Std.dev & 1. & 2. & 3. & 4. & 5. & 6. & 7. & 8. & 9. & 10. & 11. & 12. & 13. & 14. \\
\hline 1. Trickle-down & .09 & .29 & 1.00 & & & & & & & & & & & & & \\
\hline 2. Price & 2.79 & 3.15 & $-.03 *$ & 1.00 & & & & & & & & & & & & \\
\hline 3. Number of Attributes & 2.10 & 2.35 & $-.07 *$ & $.08^{*}$ & 1.00 & & & & & & & & & & & \\
\hline 4. Previous Countries & 1.18 & .60 & $.19^{*}$ & -.005 & .01 & 1.00 & & & & & & & & & & \\
\hline 5. Multinational & .23 & .42 & .002 & $-.09 *$ & $.05^{*}$ & .005 & 1.00 & & & & & & & & & \\
\hline 6. Package Size & 225.35 & 517.24 & -.003 & $.15^{*}$ & $-.04 *$ & -.004 & $-.03 *$ & 1.00 & & & & & & & & \\
\hline 7. Previous Launches & 1.33 & 1.01 & $.18^{*}$ & -.001 & -.001 & $.80 *$ & -.003 & $.01 *$ & 1.00 & & & & & & & \\
\hline $\begin{array}{l}\text { 8. Previous Countries } \\
\text { Sharing Borders }\end{array}$ & .51 & .57 & $.08^{*}$ & $.09 *$ & $.06^{*}$ & $.40^{*}$ & -.01 & $.04 *$ & $.33^{*}$ & 1.00 & & & & & & \\
\hline $\begin{array}{l}\text { 9. Previous Countries } \\
\text { Sharing Language }\end{array}$ & .66 & .63 & $.14 *$ & $.09 *$ & $.17^{*}$ & $.45^{*}$ & $-.04 *$ & $.03 *$ & $.39^{*}$ & $.22 *$ & 1.00 & & & & & \\
\hline 10. Category Experience & 98.50 & 276.31 & $-.04 *$ & $-.07 *$ & $.03 *$ & $-.02 *$ & $.54^{*}$ & $-.02 *$ & $-.02 *$ & $-.03 *$ & $-.01 *$ & 1.00 & & & & \\
\hline $\begin{array}{l}\text { 11. Experience in } \\
\text { Developed Countries }\end{array}$ & 116.93 & 264.41 & $-.05^{*}$ & $-.08^{*}$ & $.04 *$ & $-.03 *$ & $.64 *$ & $-.02 *$ & $-.03 *$ & $-.02 *$ & $-.02 *$ & $.86^{*}$ & 1.00 & & & \\
\hline $\begin{array}{l}\text { 12. Experience in } \\
\text { Emerging Countries }\end{array}$ & 44.73 & 154.08 & $-.03 *$ & $-.04 *$ & $.07 *$ & $-.02 *$ & $.49^{*}$ & $-.02 *$ & $-.02 *$ & -.01 & $.01^{*}$ & $.89 *$ & $.78^{*}$ & 1.00 & & \\
\hline 13. Small Market & .35 & .48 & $.05^{*}$ & .01 & $-.02 *$ & $.04 *$ & -.01 & -.004 & $-.02 *$ & $-.11 *$ & -.01 & $-.01 *$ & $-.03 *$ & $-.01 *$ & 1.00 & \\
\hline 14. Competition & 338.15 & 436.03 & $-.10 *$ & $.08^{*}$ & $.12^{*}$ & $-.09 *$ & $.03 *$ & $.04 *$ & $-.07 *$ & $.20^{*}$ & $.13^{*}$ & $.08^{*}$ & $.10 *$ & $.06^{*}$ & $-.36^{*}$ & 1.00 \\
\hline
\end{tabular}

${ }^{*} \mathrm{p}<.05$. VIFs are all well below 10 . The values are obtained using the variables computed to run Model $1_{\mathrm{A}}$

Table 7 Descriptives and correlations: Reverse innovation and emerging-only

\begin{tabular}{|c|c|c|c|c|c|c|c|c|c|c|c|c|c|c|c|c|}
\hline & Mean & Std.dev & 1. & 2. & 3. & 4. & 5. & 6. & 7. & 8. & 9. & 10. & 11. & 12. & 13. & 14. \\
\hline 1. Reverse Innovation & .11 & .31 & 1.00 & & & & & & & & & & & & & \\
\hline 2. Price & 1.59 & 2.08 & $.03 *$ & 1.00 & & & & & & & & & & & & \\
\hline 3. Number of Attributes & 1.57 & 2.06 & $-.03 *$ & $.21 *$ & 1.00 & & & & & & & & & & & \\
\hline 4. Previous Countries & 1.11 & .43 & $.20 *$ & -.004 & $-.02 *$ & 1.00 & & & & & & & & & & \\
\hline 5. Multinational & .14 & .35 & $.05^{*}$ & $.11 *$ & $.13^{*}$ & $.04 *$ & 1.00 & & & & & & & & & \\
\hline 6. Package Size & 213.36 & 466.03 & -.01 & $.21 *$ & $.03 *$ & -.01 & $-.02 *$ & 1.00 & & & & & & & & \\
\hline 7. Previous Launches & 1.46 & 1.80 & $.08^{*}$ & $-.03 *$ & $-.03 *$ & $.47 *$ & $-.03 *$ & $.02 *$ & 1.00 & & & & & & & \\
\hline $\begin{array}{l}\text { 8. Previous Countries } \\
\text { Sharing Borders }\end{array}$ & .42 & .51 & $.06^{*}$ & -.01 & $-.19 *$ & $.18^{*}$ & .003 & $-.03 *$ & $.07 *$ & 1.00 & & & & & & \\
\hline $\begin{array}{l}\text { 9. Previous Countries } \\
\text { Sharing Language }\end{array}$ & .56 & .56 & $.06^{*}$ & $.08^{*}$ & $-.08^{*}$ & $.32 *$ & $-.02 *$ & $-.02 *$ & $.18^{*}$ & $.33^{*}$ & 1.00 & & & & & \\
\hline 10. Category Experience & 71.45 & 280.15 & $-.02 *$ & $.03 *$ & $.08^{*}$ & -.01 & $.56^{*}$ & $-.03 *$ & $-.02 *$ & $-.02 *$ & -.004 & 1.00 & & & & \\
\hline $\begin{array}{l}\text { 11. Experience in } \\
\text { Developed Countries }\end{array}$ & 61.95 & 220.71 & -.01 & $.05^{*}$ & $.11^{*}$ & -.005 & $.64 *$ & $-.02 *$ & $-.03^{*}$ & -.005 & $-.01^{*}$ & $.88^{*}$ & 1.00 & & & \\
\hline $\begin{array}{l}\text { 12. Experience in } \\
\text { Emerging Countries }\end{array}$ & 48.83 & 174.57 & $-.02 *$ & $.04 *$ & $.11 *$ & -.01 & $.58^{*}$ & $-.02 *$ & $-.03 *$ & $-.03 *$ & $.03 *$ & $.89 *$ & $.89 *$ & 1.00 & & \\
\hline 13. Small Market & .12 & .33 & $.06^{*}$ & $10^{*}$ & $.03^{*}$ & $.04 *$ & $.10^{*}$ & -.003 & $-.03 *$ & $-.04 *$ & $-.15^{*}$ & $.06^{*}$ & $.09 *$ & $.05^{*}$ & 1.00 & \\
\hline 14. Competition & 338.87 & 461.02 & $-.13 *$ & .004 & $-.04 *$ & $-.09 *$ & $-.09 *$ & $.05 *$ & $-.06^{*}$ & $.10^{*}$ & $.11 *$ & $-.05 *$ & $-.06^{*}$ & $-.04 *$ & $-.19 *$ & 1.00 \\
\hline
\end{tabular}

$*_{\mathrm{p}}<.05$. VIFs are all well below 10 . The values are obtained using the variables computed to run Model $1_{\mathrm{B}}$ 
Open Access This article is distributed under the terms of the Creative Commons Attribution 4.0 International License (http:// creativecommons.org/licenses/by/4.0/), which permits unrestricted use, distribution, and reproduction in any medium, provided you give appropriate credit to the original author(s) and the source, provide a link to the Creative Commons license, and indicate if changes were made.

\section{References}

Abrahamson, E. (1996). Management fashion. Academy of Management Review, 21(1), 254-285.

Ackerman, D., \& Tellis, G. J. (2001). Can culture affect prices? A crosscultural study of shopping and retail prices. Journal of Retailing, 77(1), 57-82.

Bahadir, S. C., Bharadwaj, S. G., \& Srivastava, R. K. (2015). Marketing mix and brand sales in global markets: Examining the contingent role of country-market characteristics. Journal of International Business Studies, 46(5), 596-619.

Baum, J. A. C., Li, S. X., \& Usher, J. M. (2000). Making the next move: How experiential and vicarious learning shape the locations of chains' acquisitions. Administrative Science Quarterly, 45(4), 766 801.

Bikhchandani, S., Hirshleifer, D., \& Welch, I. (1998). Learning from the behavior of others: Conformity, fads, and informational cascades. Journal of Economic Perspectives, 12(3), 151-170.

Calantone, R. J., Randhawa, P., \& Voorhees, C. (2014). Breakeven time on new product launches: An investigation of the drivers and impact on firm performance. Journal of Product Innovation Management, 31(S1), 94-104.

Chandon, P. (2013). How package design and packaged-based marketing claims lead to overeating. Applied Economics. Perspectives and Policy, 35(1), 7-31.

Chandrasekaran, D., Arts, J. W. C., Tellis, G. J., \& Frambach, R. T. (2013). Pricing in the international takeoff of new products. International Journal of Research in Marketing, 30(3), 249-264.

Chandy, R. K., \& Tellis, G. J. (1998). Organizing for radical product innovation: The overlooked role of willingness to cannibalize. Journal of Marketing Research, 35(4), 474-487.

Child, J., \& Rodrigues, S. B. (2005). The internationalization of Chinese firms: A case for theoretical extension? Management and Organization Review, 1(3), 381-410.

Cillo, P., Griffith, D. A., \& Rubera, G. (2018). The new product portfolio innovativeness-stock returns relationship: The role of large individual investors' culture. Journal of Marketing, 82(6), 49-70.

Danzon, P. M., Wang, Y. R., \& Wang, L. (2005). The impact of price regulation on the launch delay of new drugs - Evidence from twenty-five major markets in the 1990s. Health Economics, 14(3), 269-292.

Dhanaraj, C., \& Beamish, P. W. (2003). A resource-based approach to the study of export performance. Journal of Small Business Management, 41(3), 242-261.

Ernst, H., Kahle, H. N., Dubiel, A., Prabhu, J. C., \& Subramaniam, M. (2015). The antecedents and consequences of affordable value innovations for emerging markets. Journal of Product Innovation Management, 32(1), 65-79.

Fligstein, N. (1985). The spread of the multidivisional form among large firms, 1919-1979. American Sociological Review, 50(3), 377-391.

Ganesh, J., Kumar, V., \& Subramaniam, V. (1997). Learning effects in multinational diffusion of consumer durables: An exploratory investigation. Journal of the Academy of Marketing Science, 25(3), 214 228
Ganesh, J., \& Kumar, V. (1996). Capturing the cross-national learning effect. An analysis of an industrial technology diffusion. Journal of the Academy of Marketing Science, 24(4), 328-337.

Gerstner, E. (1985). Do higher prices signal higher quality? Journal of Marketing Research, 22(2), 209-215.

Giachetti, C., \& Lanzolla, G. (2016). Product technology imitation over the product diffusion cycle: Which companies and product innovations do competitors imitate more quickly? Long Range Planning, 49(2), 250-264.

Govindarajan, V., \& Trimble, C. (2012). Reverse innovation, create far from home, win everywhere. Boston: Harvard Business Review Press.

Govindarajan, V., \& Ramamurti, R. (2011). Reverse innovation, emerging markets, and global strategy. Global Strategy Journal, 1(3/4), 191-205.

Gu, F. F., Hung, K., \& Tse, D. K. (2008). When does Guanxi matter? Issues of capitalization and its dark sides. Journal of Marketing, $72(4), 12-28$.

Hair, J. F., Jr., Black, W. C., Babin, B. J., \& Anderson, R. E. (2010). Multivariate Data Analysis. London: Pearson.

Hart, S. L., \& Christensen, C. M. (2002). The great leap: Driving innovation from the base of the pyramid. MIT Sloan Management Review, 44(Fall), 51-56.

Haubl, G., \& Elrod, T. (1999). The impact of congruity between brand name and country of production on consumers' product quality judgments. International Journal of Research in Marketing, 16(3), 199-215.

Haunschild, P. R., \& Miner, A. S. (1997). Modes of interorganizational imitations: The effects of outcome salience and uncertainty. Administrative Science Quarterly, 42(3), 472-500.

Head, K., Mayer, T., \& Ries, J. (2002). Revisiting oligopolistic reaction: Are decisions on foreign direct investments strategic complements? Journal of Economics and Management Strategy, 11(3), 453-472.

Heslop, L. A., \& Papadopoulos, N. (1993). Product-country imagesImpact and role in international marketing. New York: Hayworth Press.

Howard, A., Hunter, E., \& Wislo, S. (2011). U.S. Food's growing pains: Challenges in the United States and overseas. New York: Sanford C. Bernstein \& Co.

Hultink, E. J., Griffin, A., Robben, H. S. J., \& Hart, S. (1998). In search of generic launch strategies for new products. International Journal of Research in Marketing, 15(3), 269-285.

Kalish, S., Mahajan, V., \& Muller, E. (1995). Waterfall and sprinkler newproduct strategies in competitive global markets. International Journal of Research in Marketing, 12(2), 105-119.

Karagozoglu, N., \& Brown, W. B. (1993). Time-based management of the new product development process. Journal of Product Innovation Management, 10(3), 204-215.

Katsikeas, C. S., Leonidou, L. C., \& Morgan, N. A. (2000). Firm-level export performance assessment: Review, evaluation, and development. Journal of the Academy of Marketing Science, 28(4), 493511.

Kessler, E. H., \& Chakrabarti, A. K. (1999). Speeding up the pace of new product development. Journal of Product Innovation Management, 16(3), 231-247.

Kirsch, I., \& Guthrie, J. T. (1977). The concept and measurement of functional literacy. Reading Research Quarterly, 13(4), 485-507.

Kozup, J. C., Creyer, E. H., \& Burton, S. (2003). Making healthful food choices: The influence of health claims and nutrition information on consumers' evaluations of packaged food products and restaurant menu items. Journal of Marketing, 67(2), 19-34.

Kumar, V. (2014). Understanding cultural differences in innovation: A conceptual framework and future research directions. Journal of International Marketing, 22(3), 1-29.

Kumar, V., \& Krishnan, T. (2002). Multinational diffusion models: An alternative framework. Marketing Science, 21(3), 318-330. 
Kumar, V., Ganesh, J., \& Echambadi, R. (1998). cross-national diffusion research: What do we know and how certain are we? Journal of Product Innovation Management, 15(3), 255-268.

Kyle, M. K. (2007). Pharmaceutical price controls and entry strategies. Review of Economics and Statistics, 89(1), 88-99.

Kyle, M. K. (2006). The role of firm characteristics in pharmaceutical product launches. RAND Journal of Economics, 37(3), 602-618.

Lagarde, C. (2016). The role of emerging markets in a new global partnership for growth by IMF managing director Christine Lagarde [available at: https://www.imf.org/en/News/Articles/2015/09/28/ 04/53/sp020416]. Accessed 11 Nov 2018.

Lee, R. P., \& Tang, X. (2018). Does it pay to be innovation and imitation oriented? An examination of the antecedents and consequences of innovation and imitation orientations. Journal of Product Innovation Management, 35(1), 11-26.

Lee, R. P., \& Zhou, K. Z. (2012). Is product imitation good for firm performance? An examination of product imitation types and contingency factors. Journal of International Marketing, 20(3), 1-16.

Lieberman, M. B., \& Asaba, S. (2006). Why do firms imitate each other? Academy of Management Review, 31(2), 366-385.

Lieberman, M. B., \& Montgomery, D. B. (1988). First-mover advantages. Strategic Management Journal, 9(S1), 41-58.

Luo, Y., Sun, J., \& Wang, S. L. (2011). Emerging economy copycats: Capability, environment, and strategy. Academy of Management Perspectives, 25(2), 37-56.

Malhotra, N. K. (1982). Information load and consumer decision making. Journal of Consumer Research, 8(4), 419-430.

Ordanini, A., Rubera, G., \& DeFilippi, R. (2008). The many moods of organizational imitation: A critical review. International Journal of Management Reviews, 10(4), 375-398.

Prahalad, C. K. (2004). The fortune at the bottom of the pyramid: Eradicating poverty through profits. New York: Pearson Education.

Ramamurti, R., \& Singh, J. V. (2009). Emerging MNCs in emerging markets. Cambridge: Cambridge University Press.

Rubera, G., Chandrasekaran, D., \& Ordanini, A. (2016). Open innovation, product portfolio innovativeness and firm performance: The dual role of new product development capabilities. Journal of the Academy of Marketing Science, 44(2), 166-184.

Sheth, J. N. (2011). Impact of emerging markets on marketing: Rethinking existing perspectives and practices. Journal of Marketing, 75(4), 166-182.

Shinkle, G. A., \& McCann, B. T. (2014). New product deployment: The moderating influence of economic institutional context. Strategic Management Journal, 35(7), 1090-1101.

Solis, E. (2016). Mintel global new products database (GNPD). Journal of Business \& Finance Librarianship, 21(1), 79-82.

Sorescu, A. B., \& Spanjol, J. (2008). Innovation's effect on firm value and risk: Insights from consumer packaged goods. Journal of Marketing, 72(2), 114-132.
Spann, M., Fischer, M., \& Tellis, G. J. (2015). Skimming or penetration? Strategic dynamic pricing for new products. Marketing Science, 34(2), 235-249.

Sullivan, D. (1994). Measuring the degree of internationalization of a firm. Journal of International Business Studies, 25(2), 325-342.

Tellis, G. J., Stremersch, S., \& Yin, E. (2003). The international takeoff of new products: The role of economics, culture, and country innovativeness. Marketing Science, 22(2), 188-208.

Tellis, G. J. (1986). Beyond the many faces of price: An integration of pricing strategies. Journal of Marketing, 50(4), 146-160.

Townsend, J. D., Yeniyurt, S., \& Talay, M. B. (2009). Getting to global: An evolutionary perspective of brand expansion in international markets. Journal of International Business Studies, 40(4), 539-558.

UNESCO Institute for Statistics (2008). International literacy statistics: A review of concepts, methodology and current data, [available at: http://unesdoc.unesco.org/images/0016/001628/162808e.pdf]. Accessed 2 May 2017.

USPTO (2013). Can recipes be patented?, [available at: https://www. uspto.gov/custom-page/inventors-eye-advice-1]. Accessed 20 Nov 2018.

Van Heerde, H. J., Mela, C. F., \& Manchanda, P. (2004). The dynamic effect of innovation on market structure. Journal of Marketing Research, 41(2), 166-183.

Verniers, I., Stremersch, S., \& Croux, C. (2011). The global entry of new pharmaceuticals: A joint investigation of launch window and price. International Journal of Research in Marketing, 28(4), 295-308.

Von Hippel, E. (1976). The dominant role of users in the scientific instrument innovation process. Research Policy, 5(3), 212-239.

Von Zedtwitz, M., Corsi, S., Veng Søberg, P., \& Frega, R. (2015). A typology of reverse innovation. Journal of Product Innovation Management, 32(1), 12-28.

Williamson, P. J. (2010). Cost innovation: Preparing for a 'Value-forMoney' revolution. Long Range Planning, 43(2/3), 343-353.

Winter, A., \& Govindarajan, V. (2015). Engineering reverse innovations. Harvard Business Review, 93(7/8), 80-89.

Yeniyurt, S., Townsend, J. D., \& Talay, M. B. (2007). Factors influencing brand launch in a global marketplace. Journal of Product Innovation Management, 24(5), 471-485.

Zeschky, M. B., Winterhalter, S., \& Gassmann, O. (2014). From cost to frugal and reverse innovation: Mapping the field and implications for global competitiveness. Research-Technology Management, $57(4), 20-27$.

Publisher's note Springer Nature remains neutral with regard to jurisdictional claims in published maps and institutional affiliations. 